\title{
Insights on the Use of $\alpha$-Lipoic Acid for Therapeutic Purposes
}

\author{
Bahare Salehi ${ }^{1}$ (), Yakup Berkay Yılmaz ${ }^{2}$, Gizem Antika ${ }^{2}$, Tugba Boyunegmez Tumer ${ }^{3}{ }^{(0)}$, \\ Mohamad Fawzi Mahomoodally ${ }^{4}\left(\mathbb{D}\right.$, Devina Lobine ${ }^{4}\left(\mathbb{D}\right.$, Muhammad Akram ${ }^{5}{ }^{(0)}$, \\ Muhammad Riaz ${ }^{6}$, Esra Capanoglu ${ }^{7}$ (D), Farukh Sharopov ${ }^{8, *(D)}$, Natália Martins ${ }^{9,10}(\mathbb{D}$, \\ William C. Cho $11, *$ (D) and Javad Sharifi-Rad $12, *$ (D) \\ 1 Student Research Committee, School of Medicine, Bam University of Medical Sciences, Bam 44340847, Iran \\ 2 Graduate Program of Biomolecular Sciences, Institute of Natural and Applied Sciences, \\ Canakkale Onsekiz Mart University, Canakkale 17020, Turkey \\ 3 Department of Molecular Biology and Genetics, Faculty of Arts and Science, \\ Canakkale Onsekiz Mart University, Canakkale 17020, Turkey \\ 4 Department of Health Sciences; Faculty of Science, University of Mauritius, Réduit 80837, Mauritius \\ 5 Department of Eastern Medicine, Government College University Faisalabad; Faisalabad 38000, Pakistan \\ 6 Department of Allied Health Sciences, Sargodha Medical College, University of Sargodha, \\ Sargodha 40100, Pakistan \\ 7 Faculty of Chemical \& Metallurgical Engineering, Food Engineering Department, Istanbul Technical \\ University, Maslak 34469, Turkey \\ 8 Department of Pharmaceutical Technology, Avicenna Tajik State Medical University, Rudaki 139, \\ Dushanbe 734003, Tajikistan \\ 9 Faculty of Medicine, University of Porto, Alameda Prof. Hernâni Monteiro, 4200-319 Porto, Portugal \\ 10 Institute for Research and Innovation in Health (i3S), University of Porto, 4200-135 Porto, Portugal \\ 11 Department of Clinical Oncology, Queen Elizabeth Hospital, 30 Gascoigne Road, Hong Kong \\ 12 Zabol Medicinal Plants Research Center, Zabol University of Medical Sciences, Zabol 61615-585, Iran \\ * Correspondence: shfarukh@mail.ru (F.S.); chocs@ha.org.hk (W.C.C.); javad.sharifirad@gmail.com (J.S.-R.)
}

Received: 27 June 2019; Accepted: 26 July 2019; Published: 9 August 2019

Abstract: $\alpha$-lipoic acid (ALA, thioctic acid) is an organosulfur component produced from plants, animals, and humans. It has various properties, among them great antioxidant potential and is widely used as a racemic drug for diabetic polyneuropathy-associated pain and paresthesia. Naturally, ALA is located in mitochondria, where it is used as a cofactor for pyruvate dehydrogenase (PDH) and $\alpha$-ketoglutarate dehydrogenase complexes. Despite its various potentials, ALA therapeutic efficacy is relatively low due to its pharmacokinetic profile. Data suggests that ALA has a short half-life and bioavailability (about 30\%) triggered by its hepatic degradation, reduced solubility as well as instability in the stomach. However, the use of various innovative formulations has greatly improved ALA bioavailability. The R enantiomer of ALA shows better pharmacokinetic parameters, including increased bioavailability as compared to its $S$ enantiomer. Indeed, the use of amphiphilic matrices has capability to improve ALA bioavailability and intestinal absorption. Also, ALA's liquid formulations are associated with greater plasma concentration and bioavailability as compared to its solidified dosage form. Thus, improved formulations can increase both ALA absorption and bioavailability, leading to a raise in therapeutic efficacy. Interestingly, ALA bioavailability will be dependent on age, while no difference has been found for gender. The present review aims to provide an updated on studies from preclinical to clinical trials assessing ALA's usages in diabetic patients with neuropathy, obesity, central nervous system-related diseases and abnormalities in pregnancy.

Keywords: $\alpha$-lipoic acid; bioavailability; formulations; clinical trial; diabetic neuropathy; obesity; schizophrenia; sclerosis; pregnancy 


\section{Introduction}

$\alpha$-lipoic acid (ALA), also known as 1,2-dithiolane-3-pentanoic acid or thioctic acid, is a compound commonly found in mitochondria, necessary for different enzymatic functions. ALA was isolated by Reed in 1951 [1] as an acetate replacing factor and its first clinical use dates from 1959 in the treatment of acute poisoning by Amanita phalloides, also known death cap (from mushrooms) [2].

Briefly, ALA is an organosulfur compound produced from plants, animals, and humans and exists in nature. In the Krebs cycle, ALA plays important roles in various chemical reactions, acting as a cofactor for some enzymatic complexes involved in energy generation for the cell. It also forms covalent bonds with proteins and has therapeutic potential. It has a single chiral center and asymmetric carbon which results in two optical isomers: R- and S- lipoic acid (Figure 1) [3]. Thus, ALA has two enantiomeric forms, called $\mathrm{S}$ and $\mathrm{R}$ enantiomers, considered mirror images of each other. Both $\mathrm{S}$ and $\mathrm{R}$ enantiomers are present equally in ALA, being however the R isomeric form present naturally, while the $\mathrm{S}$ isomer is prepared through chemical processes. Foods are a natural source of the $\mathrm{R}$ enantiomer, naturally produced inside the living organisms forming covalent bonds with proteins. While ALA exists in nature as $\mathrm{R}$ enantiomer, synthetic supplementation consists of a racemic composition of $\mathrm{R}$ and $S$ forms [4]. Although synthetized by the human body at low amount, the ALA quantities produced are not enough to fulfill the energy requirement of the cell. Thus, it is mostly obtained from diet, especially from meat and vegetables. Fruits are also a source of this acid [5].

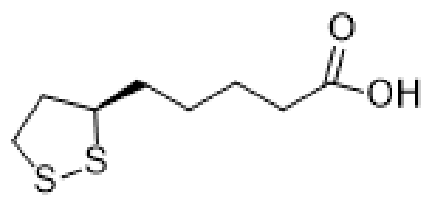

R- $\alpha$-lipoic acid

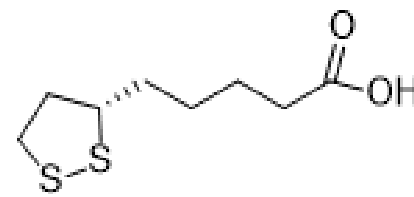

S- $\alpha$-lipoic acid

Figure 1. The chemical structure of optical isomers of ALA.

On the other hand, ALA has numerous clinically valuable properties [5,6]. It acts as an enzymatic cofactor [7] and is also involved in glucose [8,9] and lipid [10] metabolism and manages gene transcription. ALA also acts as antioxidant because it not only improves but also restores the intrinsic antioxidant systems, and supports their production or cell accessibility [11-13]. It also efficiently removes heavy metals from blood stream, responsible for oxidative stress $[11,13,14]$. The most unique characteristic of ALA over other antioxidant substances is that it reacts as both lipid and water soluble compound [5,6]. There is no doubt that it is a strong antioxidant, but due to certain reasons its use for medicinal purposes is prohibited; however, in some states it is used as a supplement and in others as a remedy $[5,6,15]$. These restrictions are due to some endogenous characteristics of substance by itself, such as the changeableness due to the disclosing of dithiolane ring and the emergence of disulfide bond between molecules. Other properties that limit the oral use of ALA are its decreased ability to become dissolved in the gastrointestinal tract and increased rate of hepatic metabolism. In addition, besides it is widely known antioxidant potential, ALA has also many other functions, as it is its involvement in mitochondria producing energy, by acting as cofactor for various enzymes involved in metabolism [5].

Moreover, ALA plays a vital role in glucose humiliation during metabolism. For instance, ALA has been applied as a racemic medication for diabetic polyneuropathy-associated pain and paresthesia [16]. ALA has also an important function in energy transduction through mitochondria [6,17]. Two reduced or oxidized thiol groups are present in the small molecule of ALA. The oxidized form is known as ALA or simply as lipoic acid, while the reduced form is noted as dihydrolipoic acid (DHLA). ALA inactivates free radicals and the reduced form also interacts with reactive oxygen species (ROS) [8]. Naturally, ALA is found in mitochondria where it binds to the E2 subunit and is used as a cofactor for both pyruvate dehydrogenase (PDH) and $\alpha$-ketoglutarate dehydrogenase complexes [18]. ALA is 
synthesized de novo at very small amounts in the body from cysteine and fatty acids, because of which there is a need to supplement it from exogenous sources [19].

ALA improves the glycemic control [6], alleviates diabetes mellitus (DM) complications [20,21] and even symptoms of peripheral neuropathy, at same time that effectively lessens the heavy metals toxicity [22].

\subsection{Forms of Lipoic Acid}

\subsubsection{R- $\alpha$-Lipoic Acid}

This isomer is present in nature, and is found in animals, plants and from human body. In nature, this is the form which ALA demonstrates its effects [23].

\subsubsection{S- $\alpha$-Lipoic Acid}

This type of isomer is not present in the nature. It may be obtained through many chemical procedures of thioctic acid and stops the important activities of R-ALA, e.g., their interaction with genes, enzymes and proteins [23].

ALA is found in many vegetables (spinach, broccoli, tomato, brussels sprouts, and rice bran), meats and entrails (e.g., liver and kidney) in lipoyllysine form (ALA with binding lysine residues). Moreover, ALA can also be synthesized by enzymatic reactions in mitochondria from octanoic acid and cysteine (as a sulfur donor) [24,25].

Both ALA and DHLA have a determinant role in oxidative metabolism [26]. For instance, it has been shown that ALA or its reduced form, DHLA have several positive health benefits, including as biological antioxidants, metal chelators and detoxification agents, being also able to reduce the oxidized forms of other antioxidant agents, including glutathione, vitamins $\mathrm{C}$ and $\mathrm{E}$, and to modulate various signaling pathways, such as insulin and nuclear factor kappa B (NF- $\mathrm{kB}$ ) [27]. It has also been used for age-associated cardiovascular, cognitive, and neuromuscular deficits [28-30], to reform endothelial dysfunction [31], to decrease oxidative stress [32] and to inhibit the formation of atherosclerosis plaque [33].

In this sense, considering the potential therapeutic actions of ALA, we aim to focus on the preclinical and clinical studies assessing the ALA pharmacological effects, also considering the aspects related with its bioavailability (Figure 2).

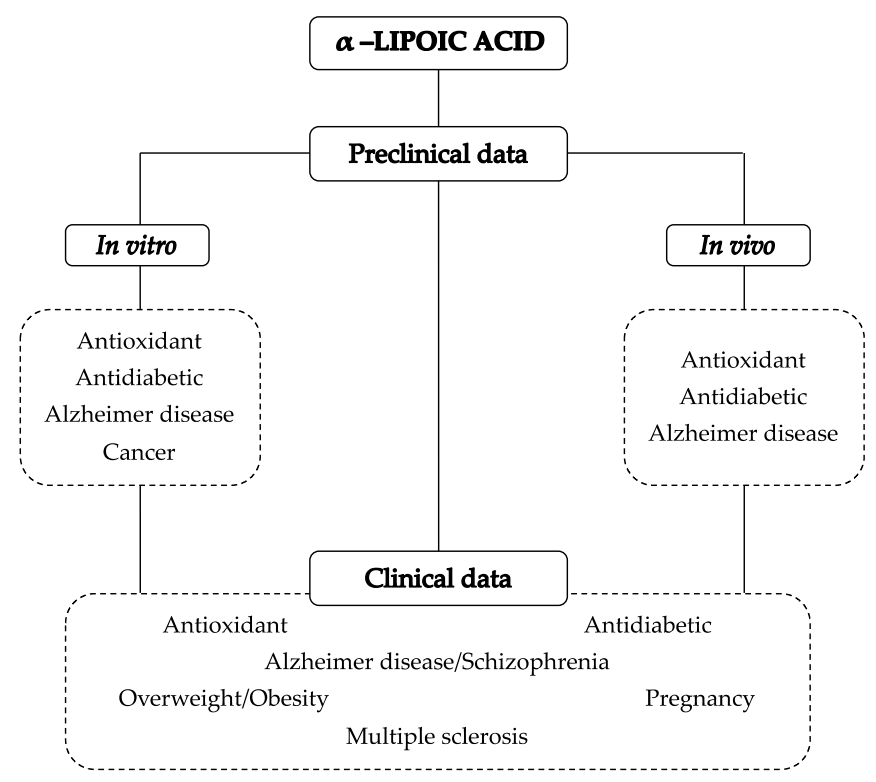

Figure 2. From preclinical to clinical effects of ALA. 


\section{Research Methodology}

The search for the above-mentioned bioactive effects and clinical impact of ALA was performed in PubMed database, articles published in English were selected, from 2014 to 2019.

\section{3. $\alpha$-Lipoic Acid Pharmacological Activities: An Overview}

Over the years, ALA has gained a considerable attention as a food additive with beneficial effects both in the treatment or management of several ailments [11,34,35]. ALA's pharmacological effects are primarily related with its antioxidant activity, but ALA and DHLA have also demonstrated interesting cardiovascular, cognitive, anti-ageing, detoxifying, anti-inflammatory, anti-cancer, and neuroprotective properties [35].

\section{1. $\alpha$-Lipoic Acid Antioxidant Potential}

There are vast literature data on ALA and DHLA antioxidant effects, namely acting as metal chelating agents, free radical scavengers, regenerator of endogenous antioxidants, such as glutathione, vitamins $\mathrm{C}$ and $\mathrm{E}$ and repair of oxidized damage [36]. The existence of thiol groups in ALA is responsible for its metal chelating abilities [14,35]. Moreover, it is able to increase the glutathione levels inside the cells, that chelate and excrete a wide variety of toxins, especially toxic metals from the body [35]. For instance, the study of Goralska et al. [37] showed that ALA administration led to a decrease in iron ions in epithelial cells. This change was associated with elevated cell resistance to hydrogen peroxide challenge, meaning that ALA exerts a direct impact in oxidative stress reduction [37]. Briefly, ALA is conceived as a biological antioxidant that is both water- and fat-soluble and is capable to neutralize ROS everywhere in the body, inside and outside the cells, and for this reason, ALA is being referred as the universal antioxidant [38-40].

\section{2. $\alpha$-Lipoic Acid Antidiabetic Potential}

Among the metabolic disorders, diabetes mellitus (DM) represent a serious health problem, currently affecting approximately 422-million people worldwide [41]. It is designated by disturbances on carbohydrates, lipids, and proteins metabolism [42]. Also, it has been recognized as a major risk factor for the development of several human diseases, including atherosclerosis, hypertension, heart failure, myocardial infarction, neuropathic pain and even stroke [43]. Emerging evidences demonstrate that DM results from the excessive ROS generation and impairment of the antioxidant potential [44-46]. Several studies have highlighted the potential use of ALA in diabetes, due to its ability to increasing both sugar uptake in insulin-sensitive and insulin-resistant muscle tissues [4,47], and to stimulate the glucose uptake by the repartition of glucose transporters to the plasma membrane, and tyrosine phosphorylation of insulin receptor substrate-1 [9].

\section{3. $\alpha$-Lipoic Acid and Alzheimer's Disease}

Alzheimer's disease (AD) is a neurological disease characterized by cognitive, functional, and behavioral alterations. Memory loss has been linked to the formation of beta-amyloid plaques and the uprise of tau in a pathological form in patients with $\mathrm{AD}[48,49]$. Substantial evidences have supported the implication of oxidative stress in the pathogenesis of AD [50-52]. Non-steroidal anti-inflammatory drugs (NSAIDs) have been proposed for the therapy of neurodegenerative diseases, including AD. However, the prolonged NSAIDs administration results in gastrointestinal toxicity due cyclooxygenase (COX) inhibition $[35,53]$. To overcome this limitation, ALA has been selected based on the intended role of oxidative stress in the development of AD.

In vitro investigations have indicated that ALA has neuroprotective effects on A $\beta$-mediated cytotoxicity [54-56], namely through defending cortical neurons from cytotoxicity induced by $A \beta$ or $\mathrm{H}_{2} \mathrm{O}_{2}$ [57], partially attributed to the activation of PKB/Akt signaling pathway. Another study revealed 
that ALA has ability to effectively protect cultured hippocampal neurons against both $\mathrm{A} \beta$ peptide and $\mathrm{Fe} / \mathrm{H}_{2} \mathrm{O}_{2}$ mediated toxicity [58].

Studies have also shown that ALA show anti-dementia or anti-AD properties by increasing acetylcholine $(\mathrm{ACh})$ production through activation of choline acetyltransferase, which increases glucose absorption and, hence, supply more acetyl-CoA for ACh production [59]. Haugaard and Levin (2000) reported that DHLA significantly increased the activity of a purified preparation of choline acetyltransferase, and that its removal by dialysis from a partially purified of choline acetyltransferase led to a complete disappearance of enzyme activity and that its addition restores activity towards normal levels. The same finding was obtained when the experiments were repeated with extracts of rat brain and heart as well as rabbit bladder tissue. Thus, the authors concluded that it may act as a coenzyme in the choline acetyltransferase reaction [60].

On the other hand, inflammation has a key function in AD. It is engaged around amyloid plaques, surrounded by activated astrocytes and microglia, and is characterized by elevated levels of free radicals and pro-inflammatory cytokines [61], with TNF- $\alpha$ being considered an indicator from mild cognitive impairment to AD $[59,62]$. ALA has multiple and complex effects in this way, namely scavenging ROS, transition metal ions, increasing the levels of reduced glutathione [59,63], scavenging of lipid peroxidation products $[62,64,65]$ and even acting on signal transduction pathways $[63,66]$. Similarly, Dinicola et al. [67] found that ALA downregulated the levels of the inflammatory cytokines IL-1B and IL-6 in SK-N-BE human neuroblastoma cells through DNA methylation-dependent modulation, paving the way for the impact of epigenetic mechanisms in AD control/prevention.

\section{4. $\alpha$-Lipoic Acid and Cancer}

An increasing body of literature highlight on the potential application of ALA in cancer therapy [68,69]. Cancer cells convert glucose preferentially to lactate for ATP generation, a phenomenon known as the Warburg effect or aerobic glycolysis. The persistent activation of aerobic glycolysis in cancerous cells lead to oncogenes activation or loss of tumor suppressors, thereby causing cancer progression. In this respect, the inhibition of aerobic cycle may contribute to anticancer effects [70,71]. Pyruvate dehydrogenase catalyzes pyruvate to acetyl CoA conversion, thus preventing lactate production. Feuerecker et al. investigated whether ALA is capable of activating pyruvate dehydrogenase in tumor cells. The results show that ALA inhibited cell proliferation, [18F]-FDG uptake and lactate formation and increased apoptosis in neuroblastoma cell lines Kelly, SK-N-SH, Neuro-2a and in the breast cancer cell line SkBr3. In the mouse xenograft model with subcutaneously $\mathrm{SkBr} 3$ cells, daily treatment with ALA has delayed tumor growth [72].

ALA suppressed thyroid cancer cell proliferation and growth through activation of AMPK and subsequent down-regulation of mTOR-S6 signaling pathway in BCPAP, HTH-83, CAL-62 and FTC-133 cells lines. In the same study, it was also found that ALA also significantly inhibited tumor growth in mouse xenograft model using BCPAP and FTC-133 cells [73]. In lung cancer cells, ALA inhibited cell proliferation through Grb2-mediated EGFR down-regulation [74].

Studies have also shown that ALA is able to generate ROS, which promote ALA-dependent cell death in lung cancer [75], breast cancer [76] and colon cancer [77,78], suggesting that it triggers the mitochondrial pathway of apoptosis in cancer cells. Recently, the effects of ALA on the migration and invasion of breast cancer cells were assessed [79]. The results have showed that ALA inhibited metastatic breast cancer cells migration and invasion, partly through ERK1/2 and AKT signaling. In summary, the scientific data show that ALA could be applied for cancer management and prevention.

\section{Preclinical Actability of $\alpha$-Lipoic Acid}

\subsection{Anti-diabetic Properties of $\alpha$-Lipoic Acid}

As previously noted, ALA have shown to be useful for increasing sugar uptake in insulin-sensitive and insulin-resistant muscle tissues [4,47]. In addition, the triglycerides' storage in the body led to 
type-2 DM progression. When activated, AMP-activated protein kinase (AMPK) increase sugar uptake, fatty acids oxidation and mitochondrial biogenesis. In obese rats, muscle AMPK levels are reduced. However, when these rats were submitted to ALA administration, a raise in insulin-stimulated glucose disposal in skeletal muscle and in the whole body was observed. ALA was also found to increase lipid oxidation and activated AMPK. These results suggest that ALA ameliorate insulin sensitivity through AMPK activation [80]. Konrad et al. [9] have demonstrated that ALA stimulates glucose uptake by the repartition of glucose transporters to the plasma membrane, and tyrosine phosphorylation of insulin receptor substrate-1. In a study carried out by Bitar et al. [81] it was found that the intake of $50 \mathrm{mg} / \mathrm{kg}$ for 30 days averted diabetes-mediated mitochondrial and endothelial dysfunction in rats, via a signal transduction pathway. It is known that in DM, the NO bioavailability is reduced through modulation of the endothelial nitric oxide synthase (eNOS) activity and oxidative stress [82]. In endothelial cells of aged rats, ALA intake resulted in a decrease in eNOS phosphorylation through Akt [83]. ALA is able to trigger Akt phosphorylation in human umbilical vascular endothelial cells and in THP-1 human monocyte cell lines $[84,85]$. These findings propose that the improved endothelial function due to ALA is partially ascribed to eNOS recoupling and increased NO bioavailability [82]. Thus, the use of ALA as an adjuvant in DM management is related to its capability to inhibit glycation which generates free radicals $[82,86,87]$. Overall, the information amassed herein indicated the potential therapeutic value of ALA for the treatment of DM.

\section{2. $\alpha$-Lipoic Acid and Alzheimer's Disease}

Given the above highlighted aspects on the use of ALA for neurodegenerative conditions, specifically in AD, Quinn et al. [88] assessed the effect of a diet supplemented with ALA on hippocampus-dependent memory of aged Tg2576 mice with AD. The authors found that ALA led to a marked improvement in learning and memory retention [88], and no significant differences were found in $\beta$-amyloid levels between ALA-treated and untreated $\operatorname{Tg} 2576$ mice [89].

\section{3. $\alpha$-Lipoic Acid and Pregnancy}

Considering the promising antioxidant potential of ALA and its impact in multiple inflammatory conditions, recent evidences have increasingly highlighted its impact in physiological processes, such as pregnancy. Interestingly, Micili et al. [90] assessed the impact of ALA vaginal administration in female Wistar rats, namely testing its tissue distribution, impact on implantation process and effectiveness in contrasting induced preterm birth. Curiously, the authors found that vaginal ALA is well-absorbed and distributed, without affecting the implantation process and was even able to significantly revert mifepristone plus prostaglandin E2 effects, thus, delaying the delivery timing and decreasing the synthesis of mRNA and pro-inflammatory cytokines release [90].

\section{Pharmacokinetics of $\alpha$-Lipoic Acid}

Although ALA has various biological activities, studies have reported a limited therapeutic efficacy due to its pharmacokinetic profile. Data suggests a short half-life and bioavailability of about $30 \%$ due to certain mechanisms, including hepatic degradation, reduced solubility as well as instability in the stomach [91]. However, this has been greatly improved through the use of various innovative formulations that directly increase ALA bioavailability.

\subsection{Bioavailability of Lipoic Acid Through Food Sources}

In plasma and human cells, the amount of ALA is not enough to meet bodily needs, unless we take it through diet. The oral intake of ALA through diet has significantly increased its amount to fulfill the energy requirement of the body. Studies have reported a $40 \%$ increase in ALA absorption when ingested the mixture of both $\mathrm{R}$ and $\mathrm{S}$ isomers orally during fasting (empty stomach), while a $20 \%$ reduction of this acid occurs when taken through food sources. The efficacy of ALA R isomer shows more stability in plasma and is properly absorbed. 
A study suggests that ALA bioavailability is greatly reduced after food intake and it has been recommended that ALA should be admitted at least $2 \mathrm{~h}$ after eating or if taken before; meal should be taken at least $30 \mathrm{~min}$ after ALA administration [92]. In addition, it has been suggested that acidic $\mathrm{pH}$ of the stomach is favorable for ALA absorption through the gastrum. Therefore, ALA supplements are preferably taken on an empty stomach to benefit of the acidic stomach $\mathrm{pH}$. Moreover, it also reduces ALA competition with other nutrients for absorption [91]. Severe renal damages, as well as food intake, influences ALA pharmacokinetic parameters [93,94]. ALA can be taken through diet to fulfill its bodily requirements and can be received from natural sources. As previously highlighted, in animals, ALA is found in red meat, kidney, liver, and heart of animals, while in plants it is found abundantly in spinach, tomatoes, broccoli, brussels sprouts, garden peas, potatoes, and rice bran [11].

\subsection{Lipoic Acid Absorption and Plasma Concentrations}

It was observed that ALA is rapidly absorbed after oral ingestion of 50 to $600 \mathrm{mg}$ thioctic acid. The time required to reach the maximum plasma concentrations was about 0.5 to $1 \mathrm{~h}$. Moreover, the maximum plasma concentrations of $R$ enantiomer were found to be 40 to 50 percent higher than the $\mathrm{S}$ enantiomer [95]. The $\mathrm{R}$ enantiomer of lipoic acid (RLA) was more rapidly absorbed through the intestine when given as an inclusion complex with $\gamma$-cyclodextrins. RLA/ $\gamma$-cyclodextrins (CD) exhibit increased plasma exposure when compared to that of non-included R-lipoic acid. Moreover, the area under the plasma concentration-time curve (AUC) was 2.2 times higher than that of the non-included RLA orally administered, and 5.1 times higher when administered intraduodenally. Moreover, the absorption was not affected, even due to administration of an amylase inhibitor during the process and ligation of the bile duct [96]. In another work, carried out to assess the absorption of a racemic ALA formulation of $600 \mathrm{mg}$, it was found that ALA takes very little time to reach the maximum plasma concentrations of $6.86 \pm 1.29 \mu \mathrm{g} / \mathrm{mL}$.

It has been noted that plasma RLA concentration is higher than that of SLA at similar doses in humans [93]. A recent study performed in rats supports similar results for maximum plasma levels, as well as the AUC being almost 1.26 times higher for RLA compared to SLA [97]. Some researchers have reported that the rate of ALA uptake is not affected by the time the stomach is emptied, as found in a study conducted in insulin-dependent diabetic patients, in whom no particular effect on ALA bioavailability was observed [93].

\subsection{Effect of Different Formulations on Lipoic acid Bioavailability}

One study used 18 subjects of both genders, including 9 females and 9 males, and pharmacokinetic parameters were observed to assess the bioavailability of ALA in these subjects. Maximum concentration of ALA in plasma, time of maximum concentration beyond the terminal ALA half-life were observed and recorded in the study of Mignini et al. [98]. Since ALA is poorly soluble, lecithin has been used as an amphiphilic matrix to enhance its bioavailability. Tablets and soft gel capsules of ALA at a dose of $600 \mathrm{mg}$ had the same bioavailability and other pharmacokinetic parameters, but were higher than those of the normally less soluble supplementation of ALA when administered to the human body [98]. It can be determined that the high bioavailability of ALA, as well as its homogenous release in vivo and high content can be increased by increasing its solubility through the use of amphiphilic matrices.

Similarly, another study determined the ALA bioavailability through different oral and intravenous (IV) formulations. The study used $200 \mathrm{mg}$ ALA through the two administration routes to determine the pharmacokinetic parameters of ALA. The IV solution was given over $4 \mathrm{~min}$, while the oral one consisted of $317.6 \mathrm{mg}$ trometanlole salt, which corresponded to $200 \mathrm{mg}$ of free ALA, 4 tablets of $50 \mathrm{mg}$ and 1 tablet of $200 \mathrm{mg}$, given to 12 healthy subjects. The IV solution was the same as the oral solution. ALA could be detected for up to $2 \mathrm{~h}$ after IV drug administration and for up to $4 \mathrm{~h}$ after oral administration. However, it was determined that the maximum plasma concentration of ALA was greater through the IV route when compared to oral administration; in addition, the terminal half-lives for both routes were comparable. A previous study reported that the bioavailability of the $\mathrm{R}$ isomer 
was greater than that of the $\mathrm{S}$ isomer for all oral administrations, while the bioavailability of the $\mathrm{R}$ isomer was maximal through oral solution [93].

It has been suggested that ALA bioavailability is markedly increased when orally administered in the liquid form rather than a solid dosage form. Moreover, it presents prolonged stability, high plasma concentrations and accelerated absorption of ALA [5,7].

\subsection{Age- and Gender-Dependent $\alpha$-Lipoic Acid Bioavailability}

Age greatly affects both ALA bioavailability and maximum plasma concentrations. Indeed, the bioavailability and peak plasma concentrations of ALA were found to be considerably higher in adults with mean age greater than 75 years as compared to young adults between the ages of 18 and 45 years. However, no significant variation in ALA bioavailability was found between males and females [17].

Another study demonstrated similar outcomes, with the exception that in tablet formulation $(600 \mathrm{mg})$, the plasma concentrations of both ALA enantiomers were higher in females than males. At low concentration, no significant differences were stated [99].

\section{6. $\alpha$-Lipoic Acid in Clinical Trials}

ALA has been extensively studied since the 1950's, when its antioxidant properties were first discovered [100]. It has been demonstrated that ALA is effective in relieving some symptoms related to certain diseases, such as diabetes, age-related cardiovascular and neuromuscular defects, antipsychotic drugs-related weight gain and metabolic obesity [29,89,101,102]. Its potential effects on different types of diseases have drawn attention, since the results from studies were promising, namely in the field of neurodegenerative conditions [103]. In addition, the number of clinical trials increased to deepen knowledge on other ALA therapeutic properties and found hopeful effects.

\subsection{The Effects of $\alpha$-Lipoic Acid on Diabetic Patients with Neuropathy}

According to the World Health Organization (WHO), the number of diabetic individuals increased from 108 million in 1980 to 422 million in 2014; and in 2016, it was estimated that 1.6 million deaths were directly caused by diabetes [41,104]. Diabetes consists of a group of diseases caused by hyperglycemia and the effects of this condition fall into two major categories: macrovascular and microvascular complications. Retinopathy, nephropathy, and neuropathy are well-characterized microvascular complications, and the development of neuropathy is closely related to the extent and duration of hyperglycemia [105]. Diabetic neuropathy has also been recognized as a major cause of morbidity and mortality [106].

Effects of ALA on diabetes-associated neuropathy have been demonstrated by numerous clinical trials (Table 1). In the randomized, double-blind, placebo-controlled, multicenter, two-arm, parallel-group trial by Ziegler et al. [107], ALA was shown to be effective against mild-to-moderate diabetic sensorimotor polyneuropathy (DSPN). The treatment of diabetic patients with mild-to-moderate DSPN with $600 \mathrm{mg}$ of ALA per day orally increased the neuropathy impairment score of lower limbs (NIS-LL) after four years. Increased NISS-LL scores greater than 2 were defined as a meaningful progression during the trial. All statistical analysis was measured in various subgroups of treatment groups. Among all subgroups, baseline subcategories with body mass index (BMI) lower than $30 \mathrm{~kg} / \mathrm{m}^{2}$, patients with type 1 diabetes, clinically relevant smokers, and angiotensin-converting-enzyme (ACE) inhibitor-treated subgroups showed mean improvement (more than -1 point) in NIS-LL in ALA-treated group after 4 years. Subgroups including male patients older than 55 years-old, who have cardiovascular disease history and neuropathy more than 3 years with DSPN stage 2a showed a remarkable increase in NIS-LL in ALA-treated group when compared to placebo group. In this trial, it was shown that ALA might have the potential to prevent the neuropathic impairments progression with regular long-term administration. However, this trial was based on mild-to-moderate DSPN and 
may not be generalized. Further studies, including more severe stages of DSPN are needed to confirm these suggestions.

Table 1. Effects of ALA in diabetic patients with neuropathy.

\begin{tabular}{|c|c|c|c|c|}
\hline Patients (n) & Design & Treatment & Key Effects & References \\
\hline $\begin{array}{l}\text { Diabetic patients } \\
\text { with } \\
\text { mild-to-moderate } \\
\text { polyneuropathy } \\
\text { Age range: n.s. } \\
\text { n = 429 }\end{array}$ & $\begin{array}{l}\text { Clinical trial } \\
\text { Randomized } \\
\text { Double-blind } \\
\text { Placebo-controlled } \\
\text { Multicenter } \\
\text { Two-arm }\end{array}$ & $\begin{array}{l}600 \mathrm{mg} / \text { day ALA or } \\
\text { placebo, orally } \\
\text { Duration: } 4 \text { years }\end{array}$ & $\begin{array}{l}\text { - Prevention of } \\
\text { neuropathic } \\
\text { improvements } \\
\text { progression with } \\
\text { regular and } \\
\text { long-term } \\
\text { administration }\end{array}$ & [107] \\
\hline $\begin{array}{l}\text { Type } 2 \text { diabetic } \\
\text { patients with } \\
\text { symptomatic } \\
\text { polyneuropathy } \\
\text { Age range: n.s. } \\
\quad \mathbf{n}=45\end{array}$ & $\begin{array}{c}\text { Clinical trial } \\
\text { Randomized } \\
\text { Withdrawal } \\
\text { Open-label study }\end{array}$ & $\begin{array}{c}600 \text { mg ALA } 3 \\
\text { times per day in } \\
\text { phase } 1 \text {, orally } \\
600 \text { mg ALA daily } \\
\text { or ALA } \\
\text { withdrawal in } \\
\text { phase } 2 \text {, orally } \\
\text { Duration: } 4 \text { weeks } \\
\text { (phase } 1 \text { ) } \\
16 \text { weeks (phase 2) }\end{array}$ & $\begin{array}{l}\text { - Phase 1: Total } \\
\text { Symptom Score } \\
\text { (TSS) decreased } \\
\text { - Phase 2: TSS } \\
\text { decreased in } \\
\text { ALA-treated group } \\
\text { and improved } \\
\text { neuropathic } \\
\text { symptoms }\end{array}$ & [108] \\
\hline $\begin{array}{c}\text { Diabetic patients } \\
\text { with early } \\
\text { nephropathy } \\
\text { Age range: n.s. } \\
\quad \mathbf{n}=62\end{array}$ & $\begin{array}{l}\text { Clinical trial } \\
\text { Randomized } \\
\text { Controlled }\end{array}$ & $\begin{array}{l}600 \mathrm{mg} / \text { day ALA, } \\
\text { intravenously with } \\
\text { routine treatment } \\
\text { or routine } \\
\text { treatment (control } \\
\text { group) } \\
\text { Duration: } 8 \text { weeks }\end{array}$ & $\begin{array}{l}\text { - Decline in urinary } \\
\text { albumin excretion } \\
\text { rates, serum } \\
\text { creatinine and } \\
\text { malonaldehyde } \\
\text { - Increased plasma } \\
\text { SOD activity and } \\
\text { improved } \\
\text { endothelium-dependent } \\
\text { flow mediated } \\
\text { vasodilation } \\
\text { flexibility }\end{array}$ & [102] \\
\hline $\begin{array}{c}\text { Diabetic patients } \\
\text { with neuropathy } \\
\text { Age range: } 18-75 \\
\mathbf{n}=72\end{array}$ & $\begin{array}{l}\text { Clinical trial } \\
\text { Clinical report } \\
\text { Interventional } \\
\text { study }\end{array}$ & $\begin{array}{c}600 \text { mg/day ALA, } \\
\text { orally } \\
\text { Duration: } 40 \text { days }\end{array}$ & $\begin{array}{l}\text { - Reduction in } \\
\text { neuropathic } \\
\text { symptoms and } \\
\text { triglycerides levels }\end{array}$ & [109] \\
\hline
\end{tabular}

In a randomized, open-label trial, ALA activities were investigated in two consecutive phases [108]. Forty-five diabetes and symptomatic polyneuropathy patients were involved in phase 1 study. All participants received $600 \mathrm{mg}$ ALA orally per day for 4 weeks and were instructed not to receive any drug that relieves neuropathic pain. Not all of the 45 patients completed the phase 1 because of patient withdrawal for personal reasons and use of prohibited drugs. After 4 weeks, patients with a Total Symptom Score (TSS) reduction more than 3 points were compared to their baseline value and continued to phase 2, where participants were randomly divided into two groups: one group continued ALA administration and the other one did not (control) for 16 weeks. The endpoint for phase 2 was the change in TSS, including burning and lancinating pain, paresthesias, and numbness. At the end of phase 2, TSS decreased in the ALA group, while no changes were stated to the control group. Furthermore, burning pain and paresthesias declined from randomization process to end of the trial; however, lancinating pain and numbness did not change in ALA-treated group in phase 2. Also, the use of analgesic rescue medication (for alleviating pain) was lower in the ALA-treated group. Thus, this trial showed that ALA improved neuropathic symptoms, while reducing the use of rescue medication in type 2 diabetes patients with symptomatic polyneuropathy. 
In the trial by Sun et al. [102], a two-stage randomized, controlled study was conducted. In the first stage, 62 patients with early-stage diabetic nephropathy were separated into control and ALA-treated groups. Both groups continued to receive regular hypoglycemic therapy (routine treatment) and strict diet; however, they were not given ACE inhibitors. In the ALA-treated group, patients received $600 \mathrm{mg}$ ALA per day intravenously for 2 weeks. In the second stage, 21 different patients were recruited for the study and divided into two groups: normoalbuminuria (urinary albumin excretion rates (UAER) lower than $30 \mathrm{mg} / 24 \mathrm{~h}$ ) and microalbuminuria (UAER 30-300 mg/24 h). During the study, only one patient had side effects (mild nausea). Exosomes quality in urine samples were assessed by electron microscopy. Serum creatinine and malondialdehyde levels, as well as UAER were decreased in ALA group. Analysis of flow-mediated vasodilation (FMD) with several parameters showed a positive correlation only with superoxide dismutase (SOD) activity. Also, it was shown that expression levels of CD63-positive exosome were higher in ALA-treated group. This trial reported that in the early diabetic neuropathy, ALA could prevent the kidney from general oxidative stress in short-term use.

Recently, a 40-day prospective, interventional trial by Agathos et al. [109] studied the action of ALA (600 mg/day, orally administered) on 72 diabetic patients with neuropathy, who were simultaneously taking their prescribed diabetic medications. Patients were scheduled to have 2 visits in 40 days: one at the beginning of the trial (baseline) and on the fortieth day (end day). In addition, blood samples were also collected to obtain baseline and second visit values. According to questionnaires results, neuropathy symptoms were reduced between the two visits. In laboratory results, mean fasting triglyceride levels were reduced significantly, whereas other parameters did not change between the two visits. Here, it was shown that ALA intake enhanced the quality of life of patients with diabetic neuropathy, reduced major symptoms and triglycerides levels.

\subsection{Effects of $\alpha$-Lipoic Acid in Overweight/Obese Patients}

Obesity is a complex disorder, consisting in an abnormal fat storage that may lead to serious pathological diseases, not only in adults but also in children. WHO global estimates showed that the rate of obesity has nearly tripled between 1975 and 2016 [110]. Additionally, overweight (BMI 25-<30) and obese (BMI $\geq 30$ ) people have a significantly higher risk for increased mortality from diabetes, kidney and cardiovascular diseases and obesity-related cancers [111]. Moreover, the dysfunctional adipose tissue is a major merging factor between obesity and other secondary chronic diseases or carcinogenesis as a result of insulin resistance, chronic inflammation and altered adipokines secretion [112]. Thus, understanding the biology of weight regulation is crucial to discover effective interventional therapies for obesity and obesity-related disorders. In addition to the classical and known therapy for obesity, which consists of a combination of low-calorie diets and physical activity, researchers are increasingly exploiting new promising nutrient supplements to interrupt the cumulative risk of obesity [113]. Recently, the effects of ALA on weight control has been investigated by clinical trials, resulting in promising results worth to mention (Table 2).

In the study of Huerta et al. [114], 77 healthy overweight/obese women with BMI values between 27.5 and $40 \mathrm{~kg} / \mathrm{m}^{2}$ were studied. All participants were randomly divided into 4 groups, treated with $1300 \mathrm{mg}$ eicosapentaenoic acid (EPA) or $300 \mathrm{mg}$ of ALA or $1300 \mathrm{mg}$ of EPA plus $300 \mathrm{mg}$ of ALA or placebo daily for 10 weeks. All individuals were adapted to 30\% energy-restricted diet during this period. Accordingly, the ALA treated group showed significantly higher body weight loss and an important drop in leptin levels from the first week of treatment, despite no significant decrease in their resting metabolic rate was stated. A notable drop in triglycerides levels and diastolic blood pressure (DBP) was found in EPA plus ALA supplemented group. In general, all groups, except EPA supplemented one, had a significant reduction in leptin levels and marked improvements in insulin level during the oral glucose tolerance test (OGTT). No unfavorable effects were stated in the clinical trial period. 
Table 2. Effects of ALA in overweight/obese patients.

\begin{tabular}{|c|c|c|c|c|}
\hline Patients (n) & Design & Treatment & Key Effects & References \\
\hline $\begin{array}{c}\text { Overweight/ } \\
\text { obese women } \\
\text { Age range: } 20-50 \\
\mathbf{n}=77\end{array}$ & $\begin{array}{l}\text { Clinical trial } \\
\text { Randomized } \\
\text { Double-blind } \\
\text { Placebo-Controlled } \\
\text { Parallel design }\end{array}$ & $\begin{array}{c}1300 \mathrm{mg} / \text { day EPA or } \\
300 \mathrm{mg} / \text { day ALA or } \\
\text { both } 1300 \mathrm{mg} / \text { day EPA } \\
+300 \mathrm{mg} / \text { day ALA or } \\
\text { placebo, orally } \\
30 \% \text { energy-restricted } \\
\text { diet } \\
\text { Duration: } 10 \text { weeks }\end{array}$ & $\begin{array}{l}\text { - Significantly higher } \\
\text { body weight loss in } \\
\text { ALA treated groups } \\
\text { - Significantly } \\
\text { attenuated decrease } \\
\text { in leptin levels in } \\
\text { ALA treated groups } \\
\text { during weight loss }\end{array}$ & [114] \\
\hline $\begin{array}{c}\text { Overweight/ } \\
\text { obese women } \\
\text { Age range: } 20-50 \\
\mathbf{n}=73\end{array}$ & $\begin{array}{l}\text { Clinical trial } \\
\text { Randomized } \\
\text { Double-blind } \\
\text { Placebo-controlled } \\
\text { Parallel design }\end{array}$ & $\begin{array}{c}1300 \mathrm{mg} / \text { day EPA or } \\
300 \mathrm{mg} / \text { day ALA or } \\
\text { both } 1300 \mathrm{mg} / \text { day EPA } \\
+300 \mathrm{mg} / \text { day ALA or } \\
\text { placebo } \\
30 \% \text { energy-restricted } \\
\text { diet } \\
\text { Duration: } 10 \text { weeks }\end{array}$ & $\begin{array}{l}\text { - A high reduction in } \\
\text { body weight, BMI } \\
\text { and fat mass was } \\
\text { stated in ALA treated } \\
\text { groups } \\
\text { - Significant } \\
\text { reduction in glucose } \\
\text { levels for only } \\
\text { control group and } \\
\text { EPA + ALA group } \\
\text { - No significant } \\
\text { differences in irisin } \\
\text { changes between } \\
\text { groups }\end{array}$ & [114] \\
\hline $\begin{array}{c}\text { Overweight or } \\
\text { obese patients } \\
\text { Age range: } 38-47 \\
\mathbf{n}=170\end{array}$ & $\begin{array}{l}\text { Clinical trial } \\
\text { Single-center } \\
\text { Randomized } \\
\text { Double-blind } \\
\text { Crossover } \\
\text { controlled }\end{array}$ & $\begin{array}{l}1200 \mathrm{mg} / \text { day ALA or } \\
\text { placebo, orally } \\
\text { Duration: } 8 \text { weeks }\end{array}$ & $\begin{array}{l}\text { - Significant } \\
\text { reduction in body } \\
\text { weight and waist } \\
\text { circumference }\end{array}$ & [115] \\
\hline $\begin{array}{c}\text { Obese patients } \\
\text { with non-alcoholic } \\
\text { fatty liver disease } \\
\text { (NAFLD) } \\
\text { Age range: } 20-50 \\
\mathbf{n}=45\end{array}$ & $\begin{array}{c}\text { Clinical trial } \\
\text { Randomized } \\
\text { Double-blind } \\
\text { Placebo-controlled }\end{array}$ & $\begin{array}{c}1200 \mathrm{mg} / \text { day ALA + } \\
400 \mathrm{mg} / \text { day vitamin E } \\
\text { or vitamin E (placebo), } \\
\text { orally } \\
\text { Duration: } 12 \text { weeks }\end{array}$ & $\begin{array}{l}\text { - Significant } \\
\text { improvement in } \\
\text { serum adiponectin } \\
\text { and IL-6 levels }\end{array}$ & [116] \\
\hline $\begin{array}{l}\text { Overweight/obese } \\
\text { women } \\
\text { Age range: not } \\
\text { specified } \\
\mathbf{n}=57\end{array}$ & $\begin{array}{c}\text { Clinical trial } \\
\text { Randomized } \\
\text { Double-blind } \\
\text { Placebo-controlled }\end{array}$ & $\begin{array}{c}300 \mathrm{mg} / \text { day ALA or } \\
1300 \mathrm{mg} / \text { day EPA or } \\
1300 \mathrm{mg} / \text { day EPA + } \\
300 \mathrm{mg} / \text { day ALA or } \\
\text { placebo, orally } \\
\text { Hypocaloric diet } \\
\text { Duration: } 10 \text { weeks }\end{array}$ & $\begin{array}{l}\text { - A significant } \\
\text { reduction in the } \\
\text { circulating levels of } \\
\text { saturated fatty acid } \\
\text { and total n-6-PUFAs }\end{array}$ & [113] \\
\hline $\begin{array}{c}\text { Overweight/ } \\
\text { obese sedentary } \\
\text { females } \\
\text { Age range: n.s. } \\
\quad \mathbf{n}=65\end{array}$ & $\begin{array}{c}\text { Clinical trial } \\
\text { Randomized } \\
\text { Double-blind } \\
\text { Placebo-controlled }\end{array}$ & $\begin{array}{c}300 \mathrm{mg} / \text { day ALA or } \\
1300 \mathrm{mg} / \text { day EPA or } \\
1300 \mathrm{mg} / \text { day EPA + } \\
300 \mathrm{mg} / \text { day ALA or } \\
\text { placebo, orally } \\
\text { Energy restricted diet } \\
\text { Duration: } 10 \text { weeks }\end{array}$ & $\begin{array}{l}\text { - Significant } \\
\text { reduction in BMI and } \\
\text { fat mass in ALA } \\
\text { treated groups }\end{array}$ & [117] \\
\hline
\end{tabular}

Huerta et al. [114] also investigated the potential relationship between circulating irisin and glucose metabolism and the effects of ALA or EPA on them. Irisin is a myokine; however, its role in obesity is not clear so far. A randomized, placebo-controlled, double-blind clinical trial with parallel design was conducted on 73 healthy overweight or obese women. The treatment groups design, supplementation doses for EPA, ALA, and the combination of EPA/ALA were identical to the above-mentioned research. Blood glucose levels demonstrated a significant decrease only in the control group and in the group of EPA and ALA combination. A considerably high significant reduction in body weight, hip circumference and fat mass were reported in ALA supplemented groups as compared to control and only EPA-treated groups. After weight loss, all groups showed decrease in irisin level; however, its concentration did not demonstrate significant differences between groups. Moreover, 
the analyses of changes in irisin level did not show significant correlation with weight loss, fat mass, and fat-free mass after 10 weeks of intervention, except for changes in insulin levels, which had positive relation. No substantial effects of ALA administration were obtained for irisin levels reduction in obese subjects. Therefore, more clinical interventions are needed in obese patients to clinically prove the effect of ALA in irisin production.

In another study, Li et al. [115] investigated the action of ALA therapy on body weight, waist circumference, and lipid metabolism in one hundred seventy overweight or obese patients (BMI $\geq 25$ $\mathrm{kg} / \mathrm{m}^{2}$ ). ALA group received orally $1200 \mathrm{mg}$ ALA per day for 8 weeks, then after a 4-week washout intervention this group continued to receive placebo for 8 weeks. The exact opposite sequence of ALA and placebo interventions was used for placebo group. According to mixed model statistical analysis, ALA administration showed a significant body weight and waist circumference reduction. However, no significant differences found to leptin levels, lipid profile and adverse effects between the two groups. Only one female subject had severe nettle-rash in the ALA group.

Hosseinpour-Arjmand et al. [116] assessed the effect of ALA on liver enzymes and inflammatory markers for non-alcoholic fatty liver disease (NAFLD), which is highly cooperating with the inflammatory components of obesity. A clinical trial was carried out on 45 obese patients with NAFLD, who received $1200 \mathrm{mg}$ ALA plus $400 \mathrm{mg}$ vitamin $\mathrm{E}$ or placebo involving $400 \mathrm{mg}$ vitamin $\mathrm{E}$ per day for 12 weeks. ALA supplementation resulted in a notable increase in serum adiponectin levels and a reduction in IL-6 as well as insulin levels compared to placebo. Significant improvement in liver steatosis grade was detected for both ALA treated group (91.3\%) and placebo group (54.5\%) compared to their baseline value; however, changes were not statistically different between two groups. In the trial, the results indicated that $1200 \mathrm{mg}$ of ALA supplementation per day was well-tolerated without any adverse effect.

In the study of Escoté et al. [113], ALA administration was involved in another clinical trial to determine the relationship between fibroblast growth factor 21 (FGF21), which play a role as energy homeostasis regulator in metabolism and fatty acid profile. Fifty-seven overweight or obese women were administered with $1300 \mathrm{mg}$ EPA or $300 \mathrm{mg}$ ALA or $1300 \mathrm{mg}$ EPA plus $300 \mathrm{mg}$ ALA or placebo daily according to four different intervention groups with energy-restricted diet for 10 weeks. At the end of the trial, no significant relation was found between plasma FGF21 levels and weight loss or total fat mass for all experimental groups.

Romo-Hualde et al. [117] investigated the metabolomic changes occurred with the supplementation of $1300 \mathrm{mg}$ EPA or $300 \mathrm{mg}$ ALA or $1300 \mathrm{mg}$ EPA plus $300 \mathrm{mg}$ ALA or placebo per day on 67 healthy overweight/obese sedentary females by following an energy-restricted diet for 10 weeks. In this study, urine samples were used for pattern recognition and characteristic metabolites identification by principal component analysis and partial least squares-discriminant analysis. A higher reduction in BMI and fat mass were found for all ALA-supplemented groups compared to EPA-treated and placebo groups. Therefore, ALA administration may have beneficial effects on body weight reduction, however further studies are warranted.

\subsection{Effects of $\alpha$-Lipoic Acid on Patients with Schizophrenia}

Schizophrenia is a serious psychiatric and dysfunctional disorder that involves many symptoms. Hallucinations, delusions, and many neurocognitive deficits, including attention and memory loss, are the well-recognized symptoms [118]. The use of antipsychotic drugs relieves these symptoms to some extent [119], but they can also lead to several side effects, such as metabolic syndrome and weight gain $[120,121]$. Herein, trials describing the actions of ALA in schizophrenic patients were summarized (Table 3). 
Table 3. Effects of ALA in schizophrenic patients.

\begin{tabular}{|c|c|c|c|c|}
\hline Patients (n) & Design & Treatment & Key Effects & References \\
\hline $\begin{array}{l}\text { Schizophrenia with } \\
\text { antipsychotic } \\
\text { induced weight gain } \\
\text { Age range: } \mathrm{n} . \mathrm{s} \\
\mathbf{n}=15\end{array}$ & $\begin{array}{c}\text { Clinical trial } \\
\text { Randomized } \\
\text { Double-blind } \\
\text { Placebo-controlled }\end{array}$ & $\begin{array}{l}600-1800 \mathrm{mg} / \text { day ALA } \\
\text { or placebo, orally } \\
\text { Duration: } 12 \text { weeks }\end{array}$ & $\begin{array}{l}\text { - Reduction in body } \\
\text { weight and BMI } \\
\text { - Significantly reduced } \\
\text { visceral fat areas } \\
\text { - No severe side effects } \\
\text { except gastrointestinal } \\
\text { symptoms and mild } \\
\text { dermatologic } \\
\text { symptoms }\end{array}$ & [101] \\
\hline $\begin{array}{l}\text { Schizophrenia } \\
\text { Age range: } 18-60 \\
\quad \mathbf{n}=10\end{array}$ & $\begin{array}{c}\text { Clinical trial } \\
\text { Open-Label Trial }\end{array}$ & $\begin{array}{c}100 \text { mg/day ALA, } \\
\text { orally } \\
\text { Duration: } 4 \text { months }\end{array}$ & $\begin{array}{c}\text { - Significant } \\
\text { improvement in } \\
\text { neurocognitive } \\
\text { parameters } \\
\text { - No significant } \\
\text { differences in BMI, } \\
\text { abdominal } \\
\text { circumference, blood } \\
\text { count and liver } \\
\text { enzymes }\end{array}$ & [122] \\
\hline $\begin{array}{l}\text { Schizophrenia } \\
\text { Age range: } 25-60 \\
\quad \mathbf{n}=18\end{array}$ & $\begin{array}{l}\text { Clinical trial } \\
\text { Controlled }\end{array}$ & $\begin{array}{c}500 \text { mg/day ALA, } \\
\text { orally } \\
\text { Duration: } 3 \text { months }\end{array}$ & $\begin{array}{l}\text { - Significant increase in } \\
\text { plasma adiponectin } \\
\text { levels } \\
\text { - Decrease in fasting } \\
\text { glucose and aspartate } \\
\text { aminotransferase } \\
\text { activity }\end{array}$ & [123] \\
\hline
\end{tabular}

In the clinical trial of Kim et al. [101], 22 patients with schizophrenia were followed for 12 weeks in a double-blind, randomized placebo-controlled trial. Patients were divided into ALA-treated $(n=10)$ and placebo $(n=12)$ groups. Patients continued to use their antipsychotic drugs during the trial. ALA was administrated orally per day $30 \mathrm{~min}$ before each meal. The ALA dosage started at $1200 \mathrm{mg} /$ day, then it was increased if the effect was not sufficient, or decreased if side effects were observed. The overall dose range for ALA was between $600-1800 \mathrm{mg} /$ day. The primary outcomes were weight loss and decreased BMI in ALA-treated group. Plasma glucose and lipid profiles, as well as abdominal fat area by fat computed tomography scan were determined at the first and last day of the trial. Accordingly, only visceral fat area was found to be notably distinct between groups; however, no significant changes were detected in both sugar and fatty acid profiles. Thus, in this trial, it was shown that ALA seems to be effective against antipsychotic drugs-related weight gain. However, only a small number of patients was involved in this trial; so, studies with larger patient groups are needed to support these findings.

Vidović et al. [123] investigated the effects of ALA in 18 patients with schizophrenia to observe how plasma adiponectin levels and some metabolic risk factors change in a controlled clinical trial. ALA was administrated to all patients at $500 \mathrm{mg} /$ day before breakfast for 3 months and patients were advised to continue to their usual dietary habits, antipsychotic drugs, and lifestyle. Blood sampling was handled at the beginning (baseline), in the middle and at the end of the trial. Fasting glucose, lipid status parameters, and liver enzymes were determined in serum samples. In addition, anthropometric measurements were analyzed including weight, height, waist circumference, and body fat. It is reported that after ALA treatment for three months, plasma adiponectin levels were increased significantly, whereas there were no remarkable changes in other factors. Furthermore, it was found a substantial reduction in fasting serum glucose and aspartate aminotransferase activity. Thus, this trial suggested that ALA may have a notable effect in the therapy of some metabolic risk factors in schizophrenia. Nevertheless, as this trial did not comprise a control group and open-label design, randomized controlled trials with larger patient groups are necessary to confirm the findings. 
Recently, an open-label trial reported the effects of ALA in 10 patients with stable chronic schizophrenia [122]. The trial was conducted for 4 months with supplementation of $100 \mathrm{mg}$ ALA/day with simultaneous use of prescribed antipsychotics. There were five visits and psychotic measurements were also obtained. At visits 1 and 5, neurocognitive assessments (Trail Making Test, Block Corsi Test, Subtest Digit Span, Category (Animal) Fluency and Controlled Oral Word Association Test, COWA (FAS test), and Rey Auditory Verbal Learning Test), collection of blood samples, measurement of abdominal circumference and body mass index (BMI) were carried out. At least a $25 \%$ decrease in negative/disorganization symptoms, including excitement (excitement, hostility, tension, grandiosity, and uncooperativeness), depression (depressive mood, guilt feelings, and motor retardation) and positive symptoms (unusual thought content, suspiciousness, and hallucinatory behavior) were observed between the first and last visits. Furthermore, there was a significant improvement in all neurocognitive tests, except for the Category (Animal) Fluency and the FAS test. There were no significant differences in abdominal circumference, BMI, complete blood count, levels of liver enzymes and other parameters. However, new trials with larger groups as well as randomized, double-blind and controlled design are needed to get reliable conclusions.

\subsection{Effects of $\alpha$-Lipoic Acid in Patients with Multiple Sclerosis}

Multiple sclerosis is a known disabling disorder of the central nervous system (CNS) and attributed to multicentric inflammation and demyelination of CNS [124]. Inflammation in MS is developed by the invasion of T cells into the CNS, then they produce the matrix metalloproteinase-9 (MMP-9), which is an important protease correlated with MS relapse. Some studies proposed that ALA may be a useful drug for MS due to its inhibitory potential on T cells and inflammatory modulators migration [125,126].

MS with changing periods of the neurological disorder and recovery periods is described as a relapsing-remitting MS (RRMS), which is the most familiar type of MS. Additionally, if the neurological damage, such as axonal loss via inflammation-mediated demyelination increases in RRMS patients, this disease is often returned into a secondary-progressive disease course (SPMS) or even rarely to the primary progressive MS (PPMS). Thus, the attention on improving therapeutic agents to restrain progressive phases of MS is expanding in recent years [127]. The effects of ALA in this aspect were also investigated through a few number of clinical trials, summarized in Table 4 .

In the study of Khalili et al. [128] the anti-inflammatory effects of daily ALA consumption on RRMS patients were investigated. Forty-six patients were randomly separated into ALA group, which received $1200 \mathrm{mg}$ ALA or placebo group, which received placebo per day for 12 weeks. A remarkable decrease in INF- $\gamma$, TGF- $\beta$, ICAM-1, and IL-4 levels was observed in ALA group when compared with the placebo group. However, no notable changes were stated in the levels of some cytokines, including TNF- $\alpha$, IL-6, EDSS, and MMP-9 through ALA administration. Therefore, this study revealed preliminary supportive data on the anti-inflammatory effect of ALA on RRMS patients; however, further studies were needed with larger patients' group to confirm these results.

The therapeutic effects of ALA on gait and balance deterioration, which are two critical symptoms for SPMS patients were investigated by Loy et al. [129]. The daily oral administration of $1200 \mathrm{mg}$ ALA was examined and compared with placebo on 21 subjects during 2 years and the improvement in physical functions was assessed by Timed Up and Go (TUG) and quiet standing tasks in the particular periods. As a result, it was reported that ALA-treated patients with less disability showed a significantly better turning time in TUG-fast task, which measures the ability of patients how much walking quickly compared to the placebo group. Thus, this pilot study enabled an expanded clinical trial of ALA treatment for walking impairment in SPMS patients. 
Table 4. Effects of ALA in patients with multiple sclerosis (MS).

\begin{tabular}{|c|c|c|c|c|}
\hline Patients (n) & Design & Treatment & Key Effects & References \\
\hline $\begin{array}{l}\text { Relapsing-remitting } \\
\text { MS } \\
\text { Age range: } 18-50 \\
\mathbf{n}=52\end{array}$ & $\begin{array}{l}\text { Clinical trial } \\
\text { Randomized } \\
\text { Double-blind } \\
\text { Placebo-controlled }\end{array}$ & $\begin{array}{l}1200 \text { mg/day ALA } \\
\text { or placebo, orally } \\
\text { Duration: } 12 \\
\text { weeks }\end{array}$ & $\begin{array}{l}\text { - Significant reduction } \\
\text { in serum levels of } \\
\text { INF- } \gamma \text {, ICAM-1 TGF- } \beta \\
\text { and IL-4 } \\
\text { - No significant } \\
\text { changes in TNF- } \alpha \text {, IL-6, } \\
\text { EDSS and MMP-9 } \\
\text { levels }\end{array}$ & [128] \\
\hline $\begin{array}{l}\text { Secondary progressive } \\
\text { multiple sclerosis } \\
\text { (SPMS) } \\
\text { Age range: } 40-70 \\
\text { n }=21\end{array}$ & $\begin{array}{l}\text { Clinical trial } \\
\text { Randomized } \\
\text { Double-blind } \\
\text { Placebo-controlled } \\
\text { Pilot study }\end{array}$ & $\begin{array}{l}1200 \mathrm{mg} / \text { day ALA } \\
\text { or placebo, orally } \\
\text { Duration: } 2 \text { years }\end{array}$ & $\begin{array}{l}\text { - Significant } \\
\text { improvements in } \\
\text { walking performance } \\
\text { in patients }\end{array}$ & [129] \\
\hline $\begin{array}{c}\text { Relapsing and } \\
\text { remitting MS (RRMS), } \\
\text { secondary progressive } \\
\text { MS (SPMS) } \\
\text { Age range: age } \geq 18 \\
\quad \mathbf{n}=57\end{array}$ & $\begin{array}{l}\text { Clinical trial } \\
\text { Controlled }\end{array}$ & $\begin{array}{l}1200 \mathrm{mg} \text { racemic } \\
\text { ALA once } \\
\text { Duration: } 48 \mathrm{~h}\end{array}$ & $\begin{array}{l}\text { - Increased cAMP at } 2 \\
\text { and } 4 \text { h of ALA } \\
\text { treatment in healthy } \\
\text { and SPMS patients } \\
\text { - Decrease cAMP in } \\
\text { RRMS patients }\end{array}$ & [130] \\
\hline
\end{tabular}

Fiedler et al. [130] designed the first clinical trial to investigate the relationship between ALA and cAMP production and also the oral bioavailability of ALA by using healthy control, RRMS, and SPMS subjects. This study was completed by 57 subjects who received $1200 \mathrm{mg}$ ALA orally for once. Blood probes were taken before and after 1, 2, 3, 4, 24 and $48 \mathrm{~h}$ from ALA administration for the cAMP measurements and ALA plasma levels by pharmacokinetic analysis. The reason for focusing on cAMP in MS patients was its inhibitory effects on proinflammatory cytokines expression and T-cells activation. Pharmacokinetics' of plasma ALA concentration was compared between the healthy control, RRMS, and SPMS groups and showed no significant differences for half-life, Tmax, Cmax, volume of distribution, and oral clearance parameters. On the other hand, increased cAMP concentration was observed in healthy and SPMS subjects at 2 and $4 \mathrm{~h}$ of post-ALA treatment compared to baseline. Also, the ALA stimulatory effect on cAMP was analyzed by measuring plasma prostaglandin E2 (PGE2) levels, which is known as a cAMP stimulator and showed a significantly higher concentration in female healthy and SPMS subjects $4 \mathrm{~h}$ after ALA taking compared to RRMS subjects. In conclusion, these obtained data concluded that although the ALA stimulatory activity on cAMP production was divergent in RRMS patients, cAMP could be used as a biomarker to trace the medicinal actions of ALA in SPMS patients.

\subsection{Effects of $\alpha$-Lipoic Acid on Abnormalities in Pregnancy}

Abnormalities in pregnancy, such as intrauterine bleeding or sub-chorionic hematomas are often associated with threatened miscarriage, especially during the first trimester of pregnancy. Sub-chorionic hematoma is a sonographically detected anechoic area with a falciform shape that increases the risk of spontaneous abortion [131]. Placental dysfunction, insufficient angiogenesis, and chronic inflammation are underlying causes of early pregnancy bleeding, and these factors can even result in preterm labor or perinatal mortality [132]. Progesterone has a significant role both in maturation of fetus and cytokine balance. Therefore, administration of progestogens is mostly used to prevent threatened miscarriage [133]. On the other hand, ALA treatment has been recently studied by some clinical trials to explain its efficacy in preventing miscarriage (Table 5). 
Table 5. Effects of ALA on abnormalities in pregnancy.

\begin{tabular}{|c|c|c|c|c|}
\hline Patients (n) & Design & Treatment & Key Effects & References \\
\hline $\begin{array}{c}\text { Threatened } \\
\text { miscarriage and } \\
\text { subchorionic } \\
\text { hematoma } \\
\text { Age range: } 20-40 \\
\mathbf{n}=16\end{array}$ & $\begin{array}{l}\text { Preliminary } \\
\text { Clinical trial } \\
\text { Randomized }\end{array}$ & $\begin{array}{c}600 \mathrm{mg} / \text { day ALA + } \\
400 \mathrm{mg} / \text { day } \\
\text { Progesterone or } \\
400 \mathrm{mg} / \text { day } \\
\text { Progesterone (control } \\
\text { group), orally } \\
\text { Duration: until } \\
\text { complete resolution of } \\
\text { the clinical picture }\end{array}$ & $\begin{array}{c}\text { - Effective } \\
\text { determination in major } \\
\text { signs of threatened } \\
\text { miscarriage in } \\
\text { ALA-treated group } \\
\text { - Significant } \\
\text { improvements for } \\
\text { hematoma resorption } \\
\text { in ALA-treated group } \\
\text { - No adverse effects on } \\
\text { mother or fetus }\end{array}$ & [134] \\
\hline $\begin{array}{l}\text { Singleton pregnancy, at } \\
\text { a gestational age } \\
\text { ranging 24-30 weeks, } \\
\text { hospitalized for a first } \\
\text { preterm labor episode } \\
\text { Age range: } \text { n.s. } \\
\mathbf{n}=32\end{array}$ & $\begin{array}{c}\text { Clinical trial } \\
\text { Randomized } \\
\text { Placebo-controlled } \\
\text { Pilot study }\end{array}$ & $\begin{array}{l}400 \mathrm{mg} / \text { day ALA } \\
\text { (active ingredient } \\
10 \mathrm{mg} \text { ) or placebo, } \\
\text { vaginal tablets } \\
\text { Duration: } 30 \text { days }\end{array}$ & $\begin{array}{l}\text { - Significant increase in } \\
\text { anti-inflammatory } \\
\text { interleukins in the } \\
\text { cervical vaginal liquids } \\
\text { of undelivered women } \\
\text { after a preterm labor } \\
\text { episode }\end{array}$ & [135] \\
\hline $\begin{array}{c}\text { Threatened } \\
\text { miscarriage } \\
\text { Age range: } 24-40 \\
\mathbf{n}=62\end{array}$ & $\begin{array}{c}\text { Clinical trial } \\
\text { Randomized } \\
\text { Controlled }\end{array}$ & $\begin{array}{c}10 \mathrm{mg} / \text { day ALA } \\
\text { (vaginal capsule) or } \\
400 \mathrm{mg} / \text { day } \\
\text { progesterone (vaginal } \\
\text { soft gel) or placebo } \\
\text { Duration: } 60 \text { days }\end{array}$ & $\begin{array}{l}\text { - quick reabsorption of } \\
\text { sub-chorionic } \\
\text { hematoma in } \\
\text { ALA-treated group } \\
\text { - Smaller number of } \\
\text { miscarriages in } \\
\text { ALA-treated group }\end{array}$ & [136] \\
\hline
\end{tabular}

A preliminary randomized clinical trial was done by Porcora et al. [134] to assess the supportive action of ALA with progesterone therapy in the recovery of sub-chorionic hematomas on 16 patients with threatened miscarriage. The subjects were between 6th and 13th week of pregnancy with pelvic pain, vaginal bleeding, and sub-chorionic hematomas. They were randomly divided into two groups. Accordingly, both control and case groups were administered with $400 \mathrm{mg}$ progesterone/day in the form of vaginal suppositories. Besides, case group was additionally treated with $600 \mathrm{mg}$ ALA/day until complete resolution of the clinical picture. Medical examinations of all subjects were carried out after a week from the enrollment, and later every fifteen days until the symptoms disappeared. During treatment, undesirable effects were not reported either in the mother or fetus. Earlier and better improvements in the symptoms of sub-chorionic hematomas were detected in the ALA plus progesterone treatment group when compared to progesterone alone. However, the change of soft uterus, which is a symptom of threatened miscarriage was not statistically significant in both groups. This study may suggest that ALA may be beneficial for health of both mother and fetus in case of threatened miscarriage.

A pilot, randomized, placebo-controlled, parallel group and monocenter study of Grandi et al. [135] studied the anti-inflammatory activities of ALA on cervical inflammation and shortening after primary tocolysis. Thirty-two women with a singleton pregnancy, at gestational age ranging 24-30 weeks and hospitalized for a first preterm labor episode were randomly recruited for the intake of $400 \mathrm{mg} /$ day of ALA in the form of vaginal hard tablets (active ingredient $10 \mathrm{mg}$ ) or placebo before sleep for 30 days. Their cervical-vaginal fluids were obtained by cervical swab to quantify the levels of pro-inflammatory cytokines before and after treatment in both groups. Moreover, cervical length tracing [122], whose shortening is a clue for preterm birth, was achieved by transvaginal ultrasound method before and after treatment. These analyses showed a notable enhance in both IL4 and IL10 levels by vaginal ALA treatment compared to placebo, while no remarkable changes were found to proinflammatory cytokines ratio between groups. Another important effect of ALA was observed in $\mathrm{CL}$ measurements. Accordingly, it was reported that the shortening of the cervix was restricted more 
effectively in vaginal ALA than in control group. Overall, these results encourage larger randomized and controlled clinical trials on this topic.

In a study, Costantino et al. [136] compared the actions of vaginal ALA or progesterone treatment in sub-chorionic hematoma resorption in 62 pregnant women with threatened miscarriage. Two treatment groups (1:1 ratio) were defined: one received $400 \mathrm{mg}$ of vaginal progesterone (vaginal soft gel) daily or $10 \mathrm{mg}$ of vaginal ALA (vaginal capsule) and one control group without treatment (upon their requests) during 60 days. The development of sub-chorionic hematoma was controlled by a vaginal ultrasound scan after 20 days and 60 days and no adverse effects on the fetus were recorded. Significant improvements and a smaller number of miscarriages were observed for the sub-chorionic hematoma resorption in the ALA-treated group, compared to progesterone group. However, no remarkable variations were recorded in pelvic pain and vaginal bleeding values in any of the groups. Therefore, these primary data support that ALA can be an effective medical route for the treatment of patients with threatened miscarriage; nevertheless, more studies are needed to confirm this usage.

\subsection{Other Trials}

There are small numbers of trials assessing the effects of ALA in organ transplantation and in case of chemotherapy.

In the work of Ambrosi et al. [137], the effects of ALA against ischemia-reperfusion injury (IRI) which occurred after simultaneous kidney-pancreas transplantation were investigated. Twenty-six patients with diabetic polyneuropathy were separated into three groups: no treatment, donor and recipient ALA-treated and only recipient ALA-treated groups. $600 \mathrm{mg}$ ALA were administrated to ALA-treated groups before surgery. The aims of including two treated groups (recipient treated-recipient and donor treated) was to figure out the influence of produced ROS at the different stages of IRI. Pancreatic and kidney biopsies were done at the end of the surgery to perform polymerase chain reaction (RT-PCR); however, the amount of biopsied tissue was not enough to perform immunohistochemical staining. Blood probes were obtained before and after surgery. The levels of serum inflammatory cytokines and other measurements were carried out. Low levels of $\mathrm{TNF} \alpha$ and $\mathrm{C} 3$ in kidneys, and high levels of heme oxygenase-1 (HMOX-1) and C3 in the pancreatic biopsies were reported. Furthermore, the decrease in IL-8, IL-6, secretory leukocyte protease inhibitor, and regenerating islet-derived protein $3 \beta$ /pancreatitis-associated protein levels were recorded in the donor-recipient treated group. This study showed that ALA can be effective in reducing inflammatory markers, kidney dysfunction and clinical pancreatitis in post-transplant patients. However, there are few studies including organ transplantation. Thus, there is a need for further randomized, placebo-controlled studies to obtain more reliable results on ALA effectiveness.

Recently, Casciato et al. [138] carried out a clinical trial in 40 liver transplant patients. Patients were divided into two groups: ALA-treated and placebo. $600 \mathrm{mg}$ of ALA was administrated to patients in the donor portal vein immediately before the cold ischemia time; then, another $600 \mathrm{mg}$ of ALA was administrated $15 \mathrm{~min}$ prior to the reperfusion. Liver tissue samples were collected from the donor and from patient $2 \mathrm{~h}$ after reperfusion. Blood probes were taken before and at the end of surgery. Samples were collected 5 times in a month after surgery. Biochemical liver parameters were also measured. High levels of hypoxia-inducible factor-1 (HIF-1 $\alpha$ ) and prolyl hydroxylase-2 (PHD2) were reported in liver biopsies for ALA-treated group, whereas no significant differences were stated to other hypoxia-related parameters. In addition, it was shown that baculoviral IAP repeat containing 2 (Birc2) transcription levels were also higher in the ALA-treated group. Also, the plasma levels of alarmins were lower in ALA-treated patients. Overall, these results suggest that the use of ALA in liver transplantation is safe as it can be protective against hypoxia and oxidative stress by inducing changes in the gene expressions at the mRNA levels.

Finally, Guo et al. [139] assessed the effect of ALA on prevention of chemotherapy-induced peripheral neuropathy. Forty cancer patients completed the trial. They were divided into two groups: ALA-treated and placebo. Further, these groups were separated to three groups according to their 
platinum exposure levels. $1800 \mathrm{mg}$ of ALA or placebo were administrated orally every day, except during the period 2 days before to 4 days after administration of each dose of platinum to avoid potential interference with platinum's antitumor effects. Neuropathic symptoms were measured at baseline and then at 24, 36, and 48 weeks of treatment. Besides, Brief Pain Inventory (BPI) Partial Forms (it included three-item questionnaires) were given to patients to learn their pain symptoms during the trial. No remarkable changes were recorded between groups for all parameters measured. It was concluded that ALA was ineffective against the neurotoxicity induced by the action of oxaliplatin or cisplatin, so that it is necessary to conduct future studies.

\section{Conclusions}

ALA has various benefits, including antioxidant potential; however, it has been shown that the therapeutic efficacy of ALA is restricted because of limitations related with its pharmacokinetic profile. Data shows a short half-life and bioavailability of about $30 \%$ of ALA due to mechanisms involving hepatic degradation, reduced ALA solubility as well as instability in the stomach. However, the use of various innovative formulations has proved to be effective in enhancing ALA bioavailability. It has been shown through studies that ALA bioavailability is enhanced through the use of amphiphilic matrices, able to enhance its solubility and absorption in the intestine. Moreover, ALA liquid formulations show greater plasma concentrations and bioavailability as compared to solid dosages. Moreover, age also affects ALA bioavailability, while gender shows insignificant differences. Thus, improved formulations that can enhance ALA absorption will markedly improve ALA bioavailability, ultimately leading to an improved therapeutic efficacy.

When looking at data from clinical trials, ALA has revealed to be efficient in particular diseases and conditions, including diabetic neuropathy, obesity, schizophrenia, MS, abnormalities in pregnancy and organ transplantation, with no or minor adverse effects. ALA seems to be also a promising agent to improve quality of life, as well as neuropathic symptoms and even to reduce the use of rescue drugs, which are commonly used by patients with diabetic neuropathy. Moreover, it has the potential to improve the lipid metabolism and promote weight reduction in obese patients, besides to alleviate CNS-related diseases (Schizophrenia and MS) symptoms. ALA may also decrease body mass gain caused by the application of prescribed antipsychotic agents, as well as some metabolic risk factors in patients with schizophrenia. In patients with MS, ALA has some positive outcomes, especially in the enhancement of walking and balance disabilities, while decreasing the levels of some proinflammatory factors related to MS progression. Therefore, the clinical trials assessing the ALA effects show its ability to alleviate some symptoms, commonly found in CNS diseases, with highly promising results. In case of threatened pregnancies, ALA demonstrated beneficial effects on the enhancement of sub-chronic hematoma symptoms, as well as positive results in miscarriage prevention, with no adverse effects. ALA is also effective in organ transplantation patients by reducing the levels of inflammatory factors and exerting protective effects against hypoxia and oxidative stress, whereas in case of neurotoxicity caused by cytotoxic chemotherapy medication ALA did not represent a protective function. Taken all together, ALA may be classified as one of the candidate molecules for prevention or slowing down some conditions associated with several diseases' progression. However, more controlled and robust clinical trials must be designed for investigating ALA therapeutic effects.

Author Contributions: All authors contributed significantly to this work. In addition, J.S.-R., B.S., N.M., W.C.C. and F.S., critically reviewed the manuscript. All authors read and approved the final manuscript.

Funding: N. Martins would like to thank the Portuguese Foundation for Science and Technology (FCT-Portugal) for the Strategic project ref. UID/BIM/04293/2013 and "NORTE2020 - Northern Regional Operational Program" (NORTE-01-0145-FEDER-000012).

Conflicts of Interest: The authors declare no conflicts of interest. 


\section{References}

1. Reed, L.J.; DeBusk, B.G.; Gunsalus, I.C.; Hornberger, C.S. Crystalline $\alpha$-lipoic acid: A catalytic agent associated with pyruvate dehydrogenase. Science 1951, 114, 93-94. [CrossRef] [PubMed]

2. Bock, E.; Schneeweiss, J. Ein Beitrag zur Therapie der Neuropathia diabetica. Munch. Med. Wochenschr. 1959, 43, 1911-1912.

3. Brookes, M.H.; Golding, B.T.; Howes, D.A.; Hudson, A.T. Proof that the absolute configuration of natural $\alpha$-lipoic acid is $\mathrm{R}$ by the synthesis of its enantiomer [(S)-(-)- $\alpha$-lipoic acid] from (S)-malic acid. J. Chem. Soc. Chem. Commun. 1983, 19, 1051-1053. [CrossRef]

4. Ghibu, S.; Richard, C.; Vergely, C.; Zeller, M.; Cottin, Y.; Rochette, L. Antioxidant properties of an endogenous thiol: Alpha-lipoic acid, useful in the prevention of cardiovascular diseases. J. Cardiovasc. Pharmacol. 2009, 54, 391-398. [CrossRef] [PubMed]

5. Brufani, M. Acido $\alpha$-lipoico farmaco o integratore. Una panoramica sulla farmacocinetica, le formulazioni disponibili e le evidenze cliniche nelle complicanze del diabete. Prog. Nutr. 2014, 16, 62-74.

6. Singh, U.; Jialal, I. Retracted: Alpha-lipoic acid supplementation and diabetes. Nutr. Rev. 2008, 66, 646-657. [CrossRef] [PubMed]

7. Maglione, E.; Marrese, C.; Migliaro, E.; Marcuccio, F.; Panico, C.; Salvati, C.; Citro, G.; Quercio, M.; Roncagliolo, F.; Torello, C.; et al. Increasing bioavailability of (R)-alpha-lipoic acid to boost antioxidant activity in the treatment of neuropathic pain. Acta Bio-Medica Atenei Parm. 2015, 86, 226-233.

8. Packer, L.; Cadenas, E. Lipoic acid: Energy metabolism and redox regulation of transcription and cell signaling. J. Clin. Biochem. Nutr. 2010, 48, 26-32. [CrossRef] [PubMed]

9. Konrad, D.; Somwar, R.; Sweeney, G.; Yaworsky, K.; Hayashi, M.; Ramlal, T.; Klip, A. The antihyperglycemic drug alpha-lipoic acid stimulates glucose uptake via both GLUT4 translocation and GLUT4 activation: Potential role of p38 mitogen-activated protein kinase in GLUT4 activation. Diabetes 2001, 50, 1464-1471. [CrossRef] [PubMed]

10. Chen, W.-L.; Kang, C.-H.; Wang, S.-G.; Lee, H.-M. $\alpha$-Lipoic acid regulates lipid metabolism through induction of sirtuin 1 (SIRT1) and activation of AMP-activated protein kinase. Diabetologia 2012, 55, 1824-1835. [CrossRef]

11. Goraca, A.; Huk-Kolega, H.; Piechota, A.; Kleniewska, P.; Ciejka, E.; Skibska, B. Lipoic acid-biological activity and therapeutic potential. Pharmacol. Rep. 2011, 63, 849-858. [CrossRef]

12. Han, D.; Handelman, G.; Marcocci, L.; Sen, C.K.; Roy, S.; Kobuchi, H.; Tritschler, H.J.; Flohé, L.; Packer, L. Lipoic acid increases de novo synthesis of cellular glutathione by improving cystine utilization. Biofactors 1997, 6, 321-338. [CrossRef] [PubMed]

13. Shay, K.P.; Moreau, R.F.; Smith, E.J.; Smith, A.R.; Hagen, T.M. Alpha-lipoic acid as a dietary supplement: Molecular mechanisms and therapeutic potential. Biochim. Biophys. Acta 2009, 1790, 1149-1160. [CrossRef] [PubMed]

14. Ou, P.; Tritschler, H.J.; Wolff, S.P. Thioctic (lipoic) acid: A therapeutic metal-chelating antioxidant? Biochem. Pharmacol. 1995, 50, 123-126. [CrossRef]

15. Bilska, A.; Wlodek, L. Lipoic acid-the drug of the future. Pharmacol. Rep. 2005, 57, 570-577.

16. Castro, M.C.; Villagarcía, H.G.; Massa, M.L.; Francini, F. Alpha-lipoic acid and its protective role in fructose induced endocrine-metabolic disturbances. Food Funct. 2019, 10, 16-25. [CrossRef] [PubMed]

17. Keith, D.J.; Butler, J.A.; Bemer, B.; Dixon, B.; Johnson, S.; Garrard, M.; Sudakin, D.L.; Christensen, J.M.; Pereira, C.; Hagen, T.M. Age and gender dependent bioavailability of R- and R,S-alpha-lipoic acid: A pilot study. Pharmacol. Res. 2012, 66, 199-206. [CrossRef]

18. Packer, L.; Witt, E.H.; Tritschler, H.J. alpha-Lipoic acid as a biological antioxidant. Free Radic. Boil. Med. 1995, 19, 227-250. [CrossRef]

19. Carreau, J.-P. [32] Biosynthesis of lipoic acid via unsaturated fatty acids. Meth. Enzymol. 1979, 62, $152-158$.

20. Ziegler, D. Thioctic acid for patients with symptomatic diabetic polyneuropathy: A critical review. Treat Endocrino 2004, 3, 173-179. [CrossRef]

21. Henriksen, E.J. Exercise training and the antioxidant alpha-lipoic acid in the treatment of insulin resistance and type 2 diabetes. Free Radic. Boil. Med. 2006, 40, 3-12. [CrossRef] [PubMed]

22. Ciftci, H.; Bakal, U. The effect of lipoic acid on macro and trace metal levels in living tissues exposed to oxidative stress. Anti-Cancer Agents Med. Chem. 2009, 9, 560-568. [CrossRef] 
23. Golbidi, S.; Badran, M.; Laher, I. Diabetes and alpha lipoic acid. Front. Pharmacol. 2011, 2, 69. [CrossRef] [PubMed]

24. Szelag, M.; Mikulski, D.; Molski, M. Quantum-chemical investigation of the structure and the antioxidant properties of $\alpha$-lipoic acid and its metabolites. J. Mol. Modeling 2012, 18, 2907-2916. [CrossRef] [PubMed]

25. Akiba, S.; Matsugo, S.; Packer, L.; Konishi, T. Assay of protein-bound lipoic acid in tissues by a new enzymatic method. Anal. Biochem. 1998, 258, 299-304. [CrossRef] [PubMed]

26. Moura, F.A.; de Andrade, K.Q.; dos Santos, J.C.; Goulart, M.O. Lipoic acid: Its antioxidant and anti-inflammatory role and clinical applications. Curr. Topics Med. Chem. 2015, 15, 458-483.

27. Gomes, M.B.; Negrato, C.A. Alpha-lipoic acid as a pleiotropic compound with potential therapeutic use in diabetes and other chronic diseases. Diabetol. Metab. Syndr. 2014, 6, 80. [CrossRef]

28. Smith, A.R.; Shenvi, S.V.; Widlansky, M.; Suh, J.H.; Hagen, T.M. Lipoic acid as a potential therapy for chronic diseases associated with oxidative stress. Curr. Med. Chem. 2004, 11, 1135-1146. [CrossRef]

29. Liu, J.; Head, E.; Gharib, A.M.; Yuan, W.; Ingersoll, R.T.; Hagen, T.M.; Cotman, C.W.; Ames, B.N. Memory loss in old rats is associated with brain mitochondrial decay and RNA/DNA oxidation: Partial reversal by feeding acetyl-L-carnitine and/or R- $\alpha$-lipoic acid. Proc. Natl. Acad. Sci. USA 2002, 99, 2356-2361. [CrossRef]

30. Han, D.; Sen, C.K.; Roy, S.; Kobayashi, M.S.; Tritschler, H.J.; Packer, L. Protection against glutamate-induced cytotoxicity in C6 glial cells by thiol antioxidants. Am. J. Physiol. Integr. Comp. Physiol. 1997, 273, 1771-1778. [CrossRef]

31. Wray, D.W.; Nishiyama, S.K.; Harris, R.A.; Zhao, J.; McDaniel, J.; Fjeldstad, A.S.; Richardson, R.S. Acute reversal of endothelial dysfunction in the elderly after antioxidant consumption. Hypertension 2012, 59, 818-824. [CrossRef] [PubMed]

32. McNeilly, A.M.; Davison, G.W.; Murphy, M.H.; Nadeem, N.; Trinick, T.; Duly, E.; McEneny, J. Effect of $\alpha$-lipoic acid and exercise training on cardiovascular disease risk in obesity with impaired glucose tolerance. Lipids Heal. Dis. 2011, 10, 217. [CrossRef] [PubMed]

33. Ying, Z.; Kherada, N.; Farrar, B.; Kampfrath, T.; Chung, Y.; Simonetti, O.; Deiuliis, J.; Desikan, R.; Khan, B.; Villamena, F.; et al. Lipoic acid effects on established atherosclerosis. Life Sci. 2010, 86, 95-102. [CrossRef] [PubMed]

34. Park, S.; Karunakaran, U.; Jeoung, N.H.; Jeon, J.-H.; Lee, I.-K. Physiological effect and therapeutic application of alpha lipoic acid. Curr. Med. Chem. 2014, 21, 3636-3645. [CrossRef] [PubMed]

35. El Barky, A.R.; Hussein, S.A.; Mohamed, T.M. The potent antioxidant alpha lipoic acid. J. Plant Chem. Ecophysiol. 2017, 2, 1016.

36. Biewenga, G.P.; Haenen, G.R.; Bast, A. The pharmacology of the antioxidant lipoic acid. Gen. Pharmacol. Vasc. Syst. 1997, 29, 315-331. [CrossRef]

37. Goralska, M.; Dackor, R.; Holley, B.; McGahan, M.C. Alpha lipoic acid changes iron uptake and storage in lens epithelial cells. Exp. Eye Res. 2003, 76, 241-248. [CrossRef]

38. Suzuki, Y.J.; Tsuchiya, M.; Packer, L. Thioctic acid and dihydrolipoic acid are novel antioxidants which interact with reactive oxygen species. Free Radic. Res. Commun. 1991, 15, 255-263. [CrossRef]

39. Scott, B.C.; Aruoma, O.I.; Evans, P.J.; O’Neill, C.; Van der Vliet, A.; Cross, C.E.; Tritschler, H.; Halliwell, B. Lipoic and dihydrolipoic acids as antioxidants. A critical evaluation. Free Radic. Res. 1994, 20, 119-133. [CrossRef]

40. Islam, M.T. Antioxidant activities of dithiol alpha-lipoic acid. Bangladesh J. Med. Sci. 2009, 8, 34-49. [CrossRef]

41. WHO. Diabetes; World Health Organization: Geneva, Switzerland, 2018.

42. Moodley, K.; Joseph, K.; Naidoo, Y.; Islam, S.; Mackraj, I. Antioxidant, antidiabetic and hypolipidemic effects of Tulbaghia violacea Harv. (wild garlic) rhizome methanolic extract in a diabetic rat model. BMC Complement. Altern. Med. 2015, 15, 408. [CrossRef] [PubMed]

43. Beckman, J.A.; Creager, M.A.; Libby, P. Diabetes and atherosclerosis: Epidemiology, pathophysiology, and management. J. Am. Med. Assoc. 2002, 287, 2570-2581. [CrossRef] [PubMed]

44. Giacco, F.; Brownlee, M. Oxidative stress and diabetic complications. Circ. Res. 2010, 107, $1058-1070$. [CrossRef] [PubMed]

45. Pitocco, D.; Tesauro, M.; Alessandro, R.; Ghirlanda, G.; Cardillo, C. Oxidative Stress in Diabetes: Implications for Vascular and Other Complications. Int. J. Mol. Sci. 2013, 14, 21525-21550. [CrossRef] [PubMed]

46. Asmat, U.; Abad, K.; Ismail, K. Diabetes mellitus and oxidative stress-A concise review. Saudi Pharm. J. 2016, 24, 547-553. [CrossRef] [PubMed] 
47. Eason, R.C.; Archer, H.E.; Akhtar, S.; Bailey, C.J. Lipoic acid increases glucose uptake by skeletal muscles of obesediabetic ob/ob mice. Diabetes Obes. Metab. 2002, 4, 29-35. [CrossRef] [PubMed]

48. García-Osta, A.; Cuadrado-Tejedor, M.; García-Barroso, C.; Oyarzábal, J.; Franco, R. Phosphodiesterases as therapeutic targets for Alzheimer's disease. ACS Chem. Neurosci. 2012, 3, 832-844. [CrossRef]

49. Wu, Y.; Li, Z.; Huang, Y.Y.; Wu, D.; Luo, H.B. Novel phosphodiesterase inhibitors for cognitive improvement in Alzheimer's disease. J. Med. Chem. 2018, 61, 5467-5483. [CrossRef] [PubMed]

50. Perry, G.; Cash, A.D.; Smith, M.A. Alzheimer disease and oxidative stress. J. Biomed. Biotechnol. 2002, 2 , 120-123. [CrossRef]

51. Chen, Z.; Zhong, C. Oxidative stress in Alzheimer's disease. Neurosci. Bull. 2014, 30, 271-281. [CrossRef]

52. Huang, W.-J.; Zhang, X.; Chen, W.-W. Role of oxidative stress in Alzheimer's disease. Biomed. Rep. 2016, 4, 519-522. [CrossRef]

53. Cacciatore, I.; Marinelli, L.; Fornasari, E.; Cerasa, L.S.; Eusepi, P.; Türkez, H.; Pomilio, C.; Reale, M.; D'Angelo, C.; Costantini, E.; et al. Novel NSAID-derived drugs for the potential treatment of Alzheimer's disease. Int. J. Mol. Sci. 2016, 17, 1035. [CrossRef] [PubMed]

54. Hagen, T.M.; Ingersoll, R.T.; Lykkesfeldt, J.; Liu, J.; Wehr, C.M.; Vinarsky, V.; Bartholomew, J.C.; Ames, A.B. (R)-alpha-lipoic acid-supplemented old rats have improved mitochondrial function, decreased oxidative damage, and increased metabolic rate. FASEB J. 1999, 13, 411-418. [CrossRef] [PubMed]

55. Farr, S.A.; Poon, H.F.; Dogrukol-Ak, D.; Drake, J.; Banks, W.A.; Eyerman, E.; Allan Butterfield, D.; Morley, J.E. The antioxidants alpha-lipoic acid and $\mathrm{N}$-acetylcysteine reverse memory impairment and brain oxidative stress in aged SAMP8 mice. J. Neurochem. 2003, 84, 1173-1183. [CrossRef] [PubMed]

56. Ono, K.; Hirohata, M.; Yamada, M. $\alpha$-Lipoic acid exhibits anti-amyloidogenicity for $\beta$-amyloid fibrils in vitro. Biochem. Biophys. Res. Commun. 2006, 341, 1046-1052. [CrossRef] [PubMed]

57. Zhang, W.-J.; Frei, B. Alpha-lipoic acid inhibits TNF-alpha-induced NF-kappaB activation and adhesion molecule expression in human aortic endothelial cells. FASEB J. 2001, 15, 2423-2432. [CrossRef] [PubMed]

58. Lovell, M.A.; Xie, C.; Xiong, S.; Markesbery, W. Protection against amyloid beta peptide and iron/hydrogen peroxide toxicity by alpha lipoic acid. J. Alzheimer's Dis. 2003, 5, 229-239. [CrossRef]

59. Holmquist, L.; Stauchbury, G.; Berbaum, K.; Muscat, S.; Young, S.; Hager, K.; Engel, J.; Münch, G. Lipoic acid as a novel treatment for Alzheimer's disease and related demenias. Pharmacol. Ther. 2007, 113, 154-164. [CrossRef]

60. Haugaard, N.; Levin, R.M. Regulation of the activity of choline acetyl transferase by lipoic acid. Mol. Cell. Biochem. 2000, 213, 61-63. [CrossRef]

61. Meraz-Ríos, M.A.; Toral-Rios, D.; Franco-Bocanegra, D.; Villeda-Hernández, J.; Campos-Peña, V. Inflammatory process in Alzheimer's disease. Front. Integr. Neurosci. 2013, 7, 59. [CrossRef]

62. Ooi, L.; Patel, M.; Münch, G. The thiol antioxidant lipoic acid and Alzheimer's disease. In Systems Biology of Free Radicals and Antioxidants; Laher, I., Ed.; Springer: Berlin/Heidelberg, Germany, 2014; pp. 2275-2288.

63. Suh, J.H.; Wang, H.; Liu, R.-M.; Liu, J.K.; Hagena, T.M. (R)- $\alpha$-Lipoic acid reverses the age-related loss in GSH redox status in post-mitotic tissues: Evidence for increased cysteine requirement for zGSH synthesis. Arch. Biochem. Biophys. 2015, 423, 126-135. [CrossRef] [PubMed]

64. Hardas, S.S.; Sultana, R.; Clark, A.M.; Beckett, T.L.; Szweda, L.I.; Murphy, P.; Butterfielda, D.A. Oxidative modification of lipoic acid by HNE in Alzheimer disease brain. Redox Biol. 2013, 1, 80-85. [CrossRef] [PubMed]

65. Breitzig, M.; Bhimineni, C.; Lockey, R.; Kolliputi, N. 4-Hydroxy-2-nonenal: A critical target in oxidative stress? Am. J. Physiol. Cell Physiol. 2016, 311, 537-543. [CrossRef] [PubMed]

66. Wong, A.; Dukic-Stefanovic, S.; Gasic-Milenkovic, J.; Schinzel, R.; Wiesinger, H.; Riederer, P.; Münch, G. Anti-inflammatory antioxidants attenuate the expression of inducible nitric oxide synthase mediated by advanced glycation endproducts in murine microglia. Eur. J. Neurosci. 2001, 14, 1961-1967. [CrossRef] [PubMed]

67. Dinicola, S.; Proietti, S.; Cucina, A.; Bizzarri, M.; Fuso, A.J.A. Alpha-Lipoic Acid Downregulates IL-1 $\beta$ and IL-6 by DNA Hypermethylation in SK-N-BE Neuroblastoma Cells. Antioxidant 2017, 6, 74. [CrossRef] [PubMed]

68. Schwartz, L.; Abolhassani, M.; Guais, A.; Sanders, E.; Steyaert, J.M.; Campion, F.; Israël, M. A combination of alpha lipoic acid and calcium hydroxycitrate is efficient against mouse cancer models: Preliminary results. Oncol. Rep. 2010, 23, 1407-1420. [CrossRef] 
69. Na, M.H.; Seo, E.Y.; Kim, W.K. Effects of alpha-lipoic acid on cell proliferation and apoptosis in MDA-MB-231 human breast cells. Nutr. Res. Pract. 2009, 3, 265-271. [CrossRef]

70. Ganapathy-Kanniappan, S.; Geschwind, J.F. Tumor glycolysis as a target for cancer therapy: Progress and prospects. Mol. Cancer 2013, 12, 152. [CrossRef]

71. Zhang, C.; Liu, J.; Liang, Y.; Wu, R.; Zhao, Y.; Hong, X.; Lin, M.; Yu, H.; Liu, L.; Levine, A.J.; et al. Tumour-associated mutant p53 drives the Warburg effect. Nat. Commun. 2013, 4, 2935. [CrossRef]

72. Feuerecker, B.; Pirsig, S.; Seidl, C.; Aichler, M.; Feuchtinger, A.; Bruchelt, G.; Senekowitsch-Schmidtke, R. Lipoic acid inhibits cell proliferation of tumor cells in vitro and in vivo. Cancer Biol. Ther. 2012, 13, 1425-1435. [CrossRef]

73. Jeon, M.J.; Kim, W.G.; Lim, S.; Choi, H.J.; Sim, S.; Kim, T.Y.; Shong, Y.K.; Kim, W.B. Alpha lipoic acid inhibits proliferation and epithelial mesenchymal transition of thyroid cancer cells. Mol. Cell. Endocrinol. 2016, 419, 113-123. [CrossRef] [PubMed]

74. Yang, L.; Wen, Y.; Lv, G.; Lin, Y.; Tang, J.; Lu, J.; Zhang, M.; Liu, W.; Sun, X. a-Lipoic acid inhibits human lung cancer cell proliferation through Grb2-mediated EGFR down regulation. Biochem. Biophys. Res. Commun. 2017, 494, 325-331. [CrossRef] [PubMed]

75. Moungjaroen, J.; Nimmannit, U.; Callery, P.S.; Wang, L.; Azad, N.; Lipipun, V.; Chanvorachote, P.; Rojanasakul, Y. Reactive oxygen species mediate caspase activation and apoptosis induced by lipoic acid in human lung epithelial cancer cells through Bcl-2 down-regulation. J. Pharmacol. Exp. Ther. 2006, 319, 1062-1069. [CrossRef] [PubMed]

76. Dozio, E.; Ruscica, M.; Passafaro, L.; Dogliotti, G.; Steffani, L.; Marthyn, P.; Pagani, A.; Demartini, G.; Esposti, D.; Fraschini, F.; et al. The natural antioxidant alpha-lipoic acid induces p27(Kip1)-dependent cell cycle arrest and apoptosis in MCF-7 human breast cancer cells. Eur. J. Pharmacol. 2010, 641, 29-34. [CrossRef] [PubMed]

77. Wenzel, U.; Nickel, A.; Daniel, H. $\alpha$-Lipoic acid induces apoptosis in human colon cancer cells by increasing mitochondrial respiration with a concomitant $\mathrm{O}^{2-*}$-generation. Apoptosis 2005, 10, 359-368. [CrossRef] [PubMed]

78. Trivedi, P.P.; Jena, G.B. Role of $\alpha$-lipoic acid in dextran sulfate sodium-induced ulcerative colitis in mice: Studies on inflammation, oxidative stress, DNA damage and fibrosis. Food Chem. Toxicol. 2013, 59, 339-355. [CrossRef]

79. Tripathy, J.; Tripathy, A.; Thangaraju, M.; Suar, M.; Elangovan, S. alpha-Lipoic acid inhibits the migration and invasion of breast cancer cells through inhibition of TGFbeta signaling. Life Sci. 2018, 207, 15-22. [CrossRef]

80. Lee, W.J.; Song, K.H.; Koh, E.H.; Won, J.C.; Kim, H.S.; Park, H.S.; Kim, M.S.; Kim, S.W.; Lee, K.U.; Park, J.Y. Alpha-lipoic acid increases insulin sensitivity by activating AMPK in skeletal muscle. Biochem. Biophys. Res. Commun. 2005, 332, 885-891. [CrossRef]

81. Bitar, M.S.; Ayed, A.K.; Abdel-Halim, S.M.; Isenovic, E.R.; Al-Mulla, F. Inflammation and apoptosis in aortic tissues of aged type II diabetes: Amelioration with lipoic acid through phosphatidylinositol 3-kinase/Akt-dependent mechanism. Life Sci. 2010, 86, 844-853. [CrossRef]

82. Rochette, L.; Ghibu, S.; Muresan, A.; Vergely, C. Alpha-lipoic acid: Molecular mechanisms and therapeutic potential in diabetes1. Can. J. Physiol. Pharmacol. 2015, 93, 1021-1027. [CrossRef]

83. Smith, A.R.; Hagen, T.M. Vascularendothelialdys- function inaging: Loss of Akt- dependent endothelial nitricoxide synthase phosphorylation and partial restoration by (R)-alpha-lipoic acid. Biochem. Soc. Trans. 2003, 31, 1447-1449. [CrossRef] [PubMed]

84. Artwohl, M.; Muth, K.; Kosulin, K.; de Martin, R.; Holzenbein, T.; Rainer, G.; Freudenthaler, A.; Huttary, N.; Schmetterer, L.; Waldhausl, W.K.; et al. R-(+)-alpha-lipoic acid inhibits endothelial cell apoptosis and proliferation: Involvement of Akt and retinoblastoma protein/E2F-1. Am. J. Physiol. Endocrinol. Metab. 2007, 293, 681-689. [CrossRef] [PubMed]

85. Zhang, W.J.; Wei, H.; Hagen, T.; Frei, B. Alpha-lipoic acid attenuates LPS-induced inflammatory responses by activating the phosphoinositide 3-kinase/Akt signaling pathway. Proc. Natl. Acad. Sci. USA 2007, 104, 4077-4082. [CrossRef] [PubMed]

86. Kawabata, T.; Packer, L. Alpha-lipoate can protect against glycation of serum albumin, but not low density lipoprotein. Biochem. Biophys. Res. Commun. 1994, 203, 99-104. [CrossRef] [PubMed]

87. Thirunavukkarasu, V.; Nandhini, A.A.T.; Anuradha, C.V. Lipoic acid improves glucose utilisation and prevents protein glycation and AGE formation. Die Pharm. 2005, 60, 772-775. 
88. Quinn, J.F.; Bussiere, J.R.; Hammond, R.S.; Montine, T.J.; Henson, E.; Jones, R.E.; Stackman, R.W. Chronic dietary alpha-lipoic acid reduces deficits in hippocampal memory of aged Tg2576 mice. Neurobiol. Aging 2007, 28, 213-225. [CrossRef] [PubMed]

89. Suh, J.H.; Zhu, B.Z.; de Szoeke, E.; Frei, B.; Hagen, T.M. Dihydrolipoic acid lowers the redox activity of transition metal ions but does not remove them from the active site of enzymes. Redox Rep. 2004, 9, 57-61. [CrossRef] [PubMed]

90. Micili, S.C.; Goker, A.; Kuscu, K.; Ergur, B.U.; Fuso, A.J.R.S. $\alpha$-Lipoic Acid Vaginal Administration Contrasts Inflammation and Preterm Delivery in Rats. Reprod. Sci. 2019, 26, 128-138. [CrossRef] [PubMed]

91. Brufani, M.; Figliola, R. (R)- $\alpha$-lipoic acid oral liquid formulation: Pharmacokinetic parameters and therapeutic efficacy. Acta Bio-Medica Atenei Parm. 2014, 85, 108-115.

92. Gleiter, C.H.; Schug, B.S.; Hermann, R.; Elze, M.; Blume, H.H.; Gundert-Remy, U. Influence of food intake on the bioavailability of thioctic acid enantiomers. Eur. J. Clin. Pharmacol. 1996, 50, 513-514. [CrossRef]

93. Hermann, R.; Niebch, G.; Borbe, H.O.; Fieger-Büschges, H.; Ruus, P.; Nowak, H.; Riethmüller-Winzen, H.; Peukert, M.; Blume, H. Enantioselective pharmacokinetics and bioavailability of different racemic $\alpha$-lipoic acid formulations in healthy volunteers. Eur. J. Pharmacol. Sci. 1996, 4, 167-174. [CrossRef]

94. Teichert, J.; Tuemmers, T.; Achenbach, H.; Preiss, C.; Hermann, R.; Ruus, P.; Preiss, R. Pharmacokinetics of alpha-lipoic acid in subjects with severe kidney damage and end-stage renal disease. J. Clin. Pharmacol. 2005, 45, 313-328. [CrossRef] [PubMed]

95. Breithaupt-Grogler, K.; Niebch, G.; Schneider, E.; Erb, K.; Hermann, R.; Blume, H.H.; Schug, B.S.; Belz, G.G. Dose-proportionality of oral thioctic acid-coincidence of assessments via pooled plasma and individual data. Eur. J. Pharm. Sci. 1999, 8, 57-65. [CrossRef]

96. Uchida, R.; Iwamoto, K.; Nagayama, S.; Miyajima, A.; Okamoto, H.; Ikuta, N.; Fukumi, H.; Terao, K.; Hirota, T. Effect of gamma-Cyclodextrin Inclusion Complex on the Absorption of R-alpha-Lipoic Acid in Rats. Int. J. Mol. Sci. 2015, 16, 10105-10120. [CrossRef] [PubMed]

97. Uchida, R.; Okamoto, H.; Ikuta, N.; Terao, K.; Hirota, T. Enantioselective Pharmacokinetics of alpha-Lipoic Acid in Rats. Int. J. Mol. Sci. 2015, 16, 22781-22794. [CrossRef] [PubMed]

98. Mignini, F.; Nasuti, C.; Gioventu, G.; Napolioni, V.; Martino, P.D. Human bioavailability and pharmacokinetic profile of different formulations delivering alpha lipoic acid. Open Access Sci. Rep. 2012, 1, 418. [CrossRef]

99. Hermann, R.; Mungo, J.; Cnota, P.J.; Ziegler, D. Enantiomer-selective pharmacokinetics, oral bioavailability, and sex effects of various alpha-lipoic acid dosage forms. Clin. Pharmacol. 2014, 6, 195-204. [CrossRef]

100. Reed, L.J. The chemistry and function of lipoic acid. Adv. Enzymol. Related Areas Mol. Biol. 1957, 18, 319-347.

101. Kim, N.W.; Song, Y.M.; Kim, E.; Cho, H.S.; Cheon, K.A.; Kim, S.J.; Park, J.Y. Adjunctive $\alpha$-lipoic acid reduces weight gain compared with placebo at 12 weeks in schizophrenic patients treated with atypical antipsychotics: A double-blind randomized placebo-controlled study. Int. Clin. Psychopharmacol. 2016, 31, 265-274. [CrossRef]

102. Sun, H.; Yao, W.; Tang, Y.; Zhuang, W.; Wu, D.; Huang, S.; Sheng, H. Urinary exosomes as a novel biomarker for evaluation of $\alpha$-lipoic acid's protective effect in early diabetic nephropathy. J. Clin. Lab. Anal. 2017, 31, e22129. [CrossRef]

103. De Sousa, C.N.S.; da Silva Leite, C.M.G.; da Silva Medeiros, I.; Vasconcelos, L.C.; Cabral, L.M.; Patrocínio, C.F.V.; Patrocínio, M.L.V.; Mouaffak, F.; Kebir, O.; Macedo, D.; et al. Alpha-lipoic acid in the treatment of psychiatric and neurological disorders: A systematic review. Metab. Brain Dis. 2019, 34, 39-52. [CrossRef] [PubMed]

104. The Emerging Risk Factors Collaboration. Diabetes mellitus, fasting blood glucose concentration, and risk of vascular disease: A collaborative meta-analysis of 102 prospective studies. Lancet 2010, 375, 2215-2222. [CrossRef]

105. Fowler, M.J. Microvascular and macrovascular complications of diabetes. Clin. Diabetes 2008, 26, 77-82. [CrossRef]

106. Vinik, A.; Casellini, C.; Nevoret, M.L. Diabetic Neuropathies. In South Dartmouth; Feingold, K.R., Anawalt, B., Boyce, A., Chrousos, G., Dungan, K., Grossman, A., Hershman, J.M., Kaltsas, G., Koch, C., Kopp, P., et al., Eds.; MDText.com, Inc.: South Dartmouth, MA, USA, 2000.

107. Ziegler, D.; Low, P.A.; Freeman, R.; Tritschler, H.J.; Vinik, A.I. Predictors of improvement and progression of diabetic polyneuropathy following treatment with $\alpha$-lipoic acid for 4 years in the NATHAN 1 trial. J. Diabetes Its Complicat. 2016, 30, 350-356. [CrossRef] [PubMed] 
108. Garcia-Alcala, H.; Santos Vichido, C.I.; Islas Macedo, S.; Genestier-Tamborero, C.N.; Minutti-Palacios, M.; Hirales Tamez, O.; Garcia, C.; Ziegler, D. Treatment with alpha-Lipoic Acid over 16 Weeks in Type 2 Diabetic Patients with Symptomatic Polyneuropathy Who Responded to Initial 4-Week High-Dose Loading. J. Diabetes Res. 2015, 2015, 189857. [CrossRef]

109. Agathos, E.; Tentolouris, A.; Eleftheriadou, I.; Katsaouni, P.; Nemtzas, I.; Petrou, A.; Papanikolaou, C.; Tentolouris, N. Effect of $\alpha$-lipoic acid on symptoms and quality of life in patients with painful diabetic neuropathy. J. Int. Med. Res. 2018, 46, 1779-1790. [CrossRef]

110. WHO. Obesity and Overweight; World Health Organization: Geneva, Switzerland, 2018.

111. Flegal, K.M.; Graubard, B.I.; Williamson, D.F.; Gail, M.H. Cause-specific excess deaths associated with underweight, overweight, and obesity. JAMA 2007, 298, 2028-2037. [CrossRef]

112. Van Kruijsdijk, R.C.M.; Van Der Wall, E.; Visseren, F.L.J. Obesity and cancer: The role of dysfunctional adipose tissue. Cancer Epidemiol. Biomarkers Prev. 2009, 18, 2569-2578. [CrossRef]

113. Escoté, X.; Félix-Soriano, E.; Gayoso, L.; Huerta, A.E.; Alvarado, M.A.; Ansorena, D.; Astiasarán, I.; Martínez, J.A.; Moreno-Aliaga, M.J. Effects of EPA and lipoic acid supplementation on circulating FGF21 and the fatty acid profile in overweight/obese women following a hypocaloric diet. Food Funct. 2018, 9 , 3028-3036. [CrossRef]

114. Huerta, A.E.; Navas-Carretero, S.; Prieto-Hontoria, P.L.; Martínez, J.A.; Moreno-Aliaga, M.J. Effects of $\alpha$-lipoic acid and eicosapentaenoic acid in overweight and obese women during weight loss. Obesity 2015, 23, 313-321. [CrossRef]

115. Li, N.; Yan, W.; Hu, X.; Huang, Y.; Wang, F.; Zhang, W.; Wang, Q.; Wang, X.; Sun, K. Effects of oral $\alpha$-lipoic acid administration on body weight in overweight or obese subjects: A crossover randomized, double-blind, placebo-controlled trial. Clin. Endocrinol. 2017, 86, 680-687. [CrossRef] [PubMed]

116. Hosseinpour-Arjmand, S.; Amirkhizi, F.; Ebrahimi-Mameghani, M. The effect of alpha-lipoic acid on inflammatory markers and body composition in obese patients with non-alcoholic fatty liver disease: A randomized, double-blind, placebo-controlled trial. J. Clin. Pharm. Ther. 2019, 44, 258-267. [CrossRef] [PubMed]

117. Romo-Hualde, A.; Huerta, A.E.; González-Navarro, C.J.; Ramos-López, O.; Moreno-Aliaga, M.J.; Martínez, J.A. Untargeted metabolomic on urine samples after $\alpha$-lipoic acid and/or eicosapentaenoic acid supplementation in healthy overweight/obese women. Lipids Health Dis. 2018, 17, 103. [CrossRef] [PubMed]

118. The American Psychiatric Association. Diagnostic and statistical manual of mental disorders; The American Psychiatric Association: Washington, DC, USA, 2013.

119. Gold, J.M. Cognitive deficits as treatment targets in schizophrenia. Schizophr. Res. 2004, 72, 21-28. [CrossRef] [PubMed]

120. Friedman, J.I.; Wallenstein, S.; Moshier, E.; Parrella, M.; White, L.; Bowler, S.; Gottlieb, S.; Harvey, P.D.; McGinn, T.G.; Flanagan, L. The effects of hypertension and body mass index on cognition in schizophrenia. Am. J. Psychiatry 2010, 167, 1232-1239. [CrossRef] [PubMed]

121. Goughari, A.S.; Mazhari, S.; Pourrahimi, A.M.; Sadeghi, M.M.; Nakhaee, N. Associations between components of metabolic syndrome and cognition in patients with schizophrenia. J. Psychiatr. Pract. 2015, 21, 190-197. [CrossRef] [PubMed]

122. Sanders, L.L.O.; de Souza Menezes, C.E.; Chaves Filho, A.J.M.; de Almeida Viana, G.; Fechine, F.V.; de Queiroz, M.G.R.; da Cruz Fonseca, S.G.; Vasconcelos, S.M.M.; de Moraes, M.E.A.; Gama, C.S. $\alpha$-Lipoic acid as adjunctive treatment for Schizophrenia: An open-label trial. J. Clin. Psychopharmacol. 2017, 37, 697-701. [CrossRef] [PubMed]

123. Vidović, B.; Milovanović, S.; Stefanović, A.; Kotur-Stevuljević, J.; Takić, M.; Debeljak-Martačić, J.; Pantović, M.; Đorđević, B. Effects of alpha-lipoic acid supplementation on plasma adiponectin levels and some metabolic risk factors in patients with schizophrenia. J. Med. Food 2017, 20, 79-85. [CrossRef]

124. Confavreux, C.; Vukusic, S.; Moreau, T.; Adeleine, P. Relapses and progression of disability in multiple sclerosis. N. Engl. J. Med. 2000, 343, 1430-1438. [CrossRef]

125. Marracci, G.H.; Jones, R.E.; McKeon, G.P.; Bourdette, D.N. Alpha lipoic acid inhibits T cell migration into the spinal cord and suppresses and treats experimental autoimmune encephalomyelitis. J. Neuroimmunol. 2002, 131, 104-114. [CrossRef] 
126. Yadav, V.; Marracci, G.; Lovera, J.; Woodward, W.; Bogardus, K.; Marquardt, W.; Shinto, L.; Morris, C.; Bourdette, D. Lipoic acid in multiple sclerosis: A pilot study. Mult. Scler. J. 2005, 11, 159-165. [CrossRef] [PubMed]

127. Dutta, R.; Trapp, B.D. Relapsing and progressive forms of multiple sclerosis-insights from pathology. Curr. Opin. Neurol. 2014, 27, 271-278. [CrossRef] [PubMed]

128. Khalili, M.; Azimi, A.; Izadi, V.; Eghtesadi, S.; Mirshafiey, A.; Sahraian, M.A.; Motevalian, A.; Norouzi, A.; Sanoobar, M.; Eskandari, G.; et al. Does lipoic acid consumption affect the cytokine profile in multiple sclerosis patients: A double-blind, placebo-controlled, randomized clinical trial. Neuroimmunomodulation 2014, 21, 291-296. [CrossRef] [PubMed]

129. Loy, B.D.; Fling, B.W.; Horak, F.B.; Bourdette, D.N.; Spain, R.I. Effects of lipoic acid on walking performance, gait, and balance in secondary progressive multiple sclerosis. Complement. Ther. Med. 2018, 41, 169-174. [CrossRef] [PubMed]

130. Fiedler, S.E.; Yadav, V.; Kerns, A.R.; Tsang, C.; Markwardt, S.; Kim, E.; Spain, R.; Bourdette, D.; Salinthone, S. Lipoic acid stimulates cAMP production in healthy control and secondary progressive MS subjects. Mol. Neurobiol. 2018, 55, 6037-6049. [CrossRef] [PubMed]

131. Yamada, T.; Atsuki, Y.; Wakasaya, A.; Kobayashi, M.; Hirano, Y.; Ohwada, M. Characteristics of patients with subchorionic hematomas in the second trimester. J. Obstet. Gynaecol. Res. 2012, 38, 180-184. [CrossRef] [PubMed]

132. Şükür, Y.E.; Göç, G.; Köse, O.; Açmaz, G.; Özmen, B.; Atabekoğlu, C.S.; Koç, A.; Söylemez, F. The effects of subchorionic hematoma on pregnancy outcome in patients with threatened abortion. J. Turkish German Gynecol. Assoc. 2014, 15, 239. [CrossRef] [PubMed]

133. Carp, H.J.A. Progestogens and pregnancy loss. Climacteric 2018, 21, 380-384. [CrossRef]

134. Porcaro, G.; Brillo, E.; Giardina, I.; Di Iorio, R. Alpha Lipoic Acid (ALA) effects on subchorionic hematoma: Preliminary clinical results. Eur. Rev. Med. Pharmacol. Sci. 2015, 19, 3426-3432.

135. Grandi, G.; Pignatti, L.; Ferrari, F.; Dante, G.; Neri, I.; Facchinetti, F. Vaginal alpha-lipoic acid shows an anti-inflammatory effect on the cervix, preventing its shortening after primary tocolysis. A pilot, randomized, placebo-controlled study. J. Matern. Fetal Neonatal Med. 2017, 30, 2243-2249. [CrossRef]

136. Costantino, M.; Guaraldi, C.; Costantino, D. Resolution of subchorionic hematoma and symptoms of threatened miscarriage using vaginal alpha lipoic acid or progesterone: Clinical evidences. Eur. Rev. Med. Pharmacol. Sci. 2016, 20, 1656-1663. [PubMed]

137. Ambrosi, N.; Arrosagaray, V.; Guerrieri, D.; Uva, P.D.; Petroni, J.; Herrera, M.B.; Iovanna, J.L.; Leon, L.; Incardona, C.; Chuluyan, H.E.; et al. alpha-Lipoic acid protects against ischemia-reperfusion injury in simultaneous kidney-pancreas transplantation. Transplantation 2016, 100, 908-915. [CrossRef] [PubMed]

138. Casciato, P.; Ambrosi, N.; Caro, F.; Vazquez, M.; Müllen, E.; Gadano, A.; de Santibañes, E.; de Santibañes, M.; Zandomeni, M.; Chahdi, M. $\alpha$-Lipoic acid reduces postreperfusion syndrome in human liver transplantation-a pilot study. Transpl. Int. 2018, 31, 1357-1368. [CrossRef] [PubMed]

139. Guo, Y.; Jones, D.; Palmer, J.L.; Forman, A.; Dakhil, S.R.; Velasco, M.R.; Weiss, M.; Gilman, P.; Mills, G.M.; Noga, S.J.; et al. Oral alpha-lipoic acid to prevent chemotherapy-induced peripheral neuropathy: A randomized, double-blind, placebo-controlled trial. Support. Care Cancer 2014, 22, 1223-1231. [CrossRef] [PubMed]

(C) 2019 by the authors. Licensee MDPI, Basel, Switzerland. This article is an open access article distributed under the terms and conditions of the Creative Commons Attribution (CC BY) license (http://creativecommons.org/licenses/by/4.0/). 